Nov ${ }_{1} 1991$

\title{
Tank 241-A-105 Leak Assessment
}

Prepared for the U.S. Department of Energy Office of Environmental Restoration and Waste Management

\section{(2.) Westinghouse \\ Hanford Company Richland, Washington}

Hanford Operations and Engineering Contractor for the

U.S. Department of Energy under Contract DE-AC06-87RL10930 


\section{LEGAL DISCLAIMER}

This report was prepared as an account of work sponsored by an agency of the United States Government. Neither the United States Government nor any agency thereof, nor any of their employees, nor any of their contractors, subcontractors or their employees, makes any warranty, express or implied, or assumes any legal liability or responsibility for the accuracy, completeness, or any third party's use or the results of such use of any information, apparatus, product, or process disclosed, or represents that its use would not infringe privately owned rights. Reference herein to any specific commercial product, process, or service by trade name, trademark, manufacturer, or otherwise. does not necessarily constitute or imply its endorsement, recommendation, or favering by the United States Government or any agency thereof or its contractors or subcontractors. The views and upinions of authors expressed herein do not necessarily state or refiect those of the United States Government or any agency thereof.

This report has been reproduced from the best available copy.

Printod in the Uniled Slates of America

DISCLM-2.CHP (1.91) 
WHC-MR- -0264

DE92 002047

\section{Tank 241-A-105 \\ Leak Assessment}

Date Published

June 1991

Prepared for the U.S. Department of Energy Office of Environmental Restoration and Waste Management

(2) Westinghouse P.O. Box 1970

Hanford Company Richland, Washington 99352

Hanford Operations and Engineering Contractor for the

U.S. Department of Energy under Contract DE-AC06-87RL10930 


\section{PREFACE}

On April 27, 1989 the Department of Energy, Richland Operations Office (DOE-RL) requested Westinghouse Hanford Company (WHC) to conduct a review of estimated leak volumes for the single-shell tanks (ref. 8901832B DOE-RL letter, "Single-Shell Tank Leak Volumes" G.J. Bracken to President, WHC).

Subsequently, WHC undertook a comprehensive review of leaks from the single-shell tanks located on the Hanford Site. On September 28, 1990, Mr. Roger Stanley of the State of Washington, Department of Ecology issued a letter to DOE-RL raising specific concerns about the volume of cooling water added to waste tank 241-A-105 and potential leakage of waste from this tank.

As a result of DOE-RL and Ecology inquiry, in January, 1991, WHC contracted with Ebasco Services Inc. to provide an independent assessment of the volume and radioactive content of the effluent that leaked from waste tank 241-A-105. Ebasco was directed to review all previous leak studies pertaining to the tank with respect to validity of assumptions and quality of data. Ebasco was further directed to seek out all new data available on this tank and apply this data to develop an updated leakage assessment. The following study is the result of an exhaustive and lengthy literature search and a careful engineering analysis of the results of that search. 
TANK 241-A-105

LEAK ASSESSMENT

June 7, 1991

Submitted to

\section{WESTINGHOUSE HANFORD COMPANY}

Task Order No. E-91-10 of Order MLW-SVV-037106

Prepared by EBASCO SERVICES INCORPORATED

Richland, Washington 


\section{DISCLAMMER}

This report was prepared as an account of work sponsored by the United States government Neither the United States nor the Department of Energy, nor any of their einployees, makes any warranty, expressed or implied, nor assumes any legal liability or responsibility for the accuracy, completeness, or usefulness of any information, apparatus, product, or process disclosed, or represents that its use would not infringe privately owned rights. Reference herein to any specific commercial product, process, or service by trade name, mark, manufacturer, or otherwise, does not necessarily constitute or imply its endorsement, recommendation, or favoring by the United States Government, any agency thereof, or any contractor or subcontractor. The views and opinions of authors expressed herein do not necessarily state or reflect those of the United States Government, any agency thereof, or any contractor or subcontractor. 


\section{EXECUTIVE SUMMARY}

Tank 241-A-105 is one of 149 single shell tanks constructed at Hanford to contain and store highly radioactive wastes originating from the processing of spent nuclear reactor fuel. Records indicate that the tank was breached in 1965, but was used to contain liquid waste until August 1968. Following sluicing to remove the bulk of the settled waste sludge, water was sprinkled on top of the residual sludge for eight years to prevent overheating as a result of the thermal decay of radioisotopes contained within the sludge. Since 1978 cooling of the tank has been accomplished by drawing outside air through the tank vapor space and exhausting it back to the atmosphere following filtration.

Radiation detection and temperature monitoring devices installed beneath the tank indicate that several episcdes of leakage of waste from the tank have occurred. Previous estimates of water leaking from the tank have ranged from 5,000 gallons to 960,000 gallons. The aim of this study was to evaluate the previous estimates and reanalyze the data to provide a more accurate estimate of leakage from the tank.

The principal conclusions of this study are as follows:

1. Earlier investigators estimated leakage prior to August 1968 at 5,000 to 15,000 gallons. Their estimate appears reasonable.

2. Leakage while the tank was being sluiced $(8 / 68-11 / 70)$ probably exceeded 5,000 gallons, but probably did not exceed 30,000 gallons. Insufficient data are available to be more precise.

3. Cooling water added to the tank during the sprinkling phase $(11 / 70-12 / 78)$ was approximately 610,000 gallons. Sufficient heat was generated in the tank to evaporate most, and perhaps nearly all, of this water. Although some activity was seen in the radiation laterals under the tank, no evidence was found of significant leakage of radionuclides during this period, compared with the previous periods. 
4. Radionuclides escaping into the soil under the tank cannot be estimated directly because of many uncertainties. Based on a range of leakage from 10,000 to 45,000 gallons, assumed compositions, and decayed to $1 / 1 / 91$, radioactivity under the tank is expected to be in the range of $85,000-760,000$ curies. Of this, $99.9 \%$ is from $\mathrm{Cs}-137,0.1 \%$ from $\mathrm{Sr}-90$, the same ratio of these radionuclides that existed in the waste supernate. We assume no sludge leaked from the tank.

To judge the extent of leakage, the writers reviewed the contents of 89 boxes of documents from the Federal Records Center in Seattle, Washington. Included in these boxes were the original logs of radiation probe traverses through pipe laterals installed in a horizontal plane 10 feet below the tank. The measured radiation peaks were neariy all located directly below the perimeter of the tank and, except in rare cases, they showed no tendency to spread horizontally. Had the leaks been large, and backed up by the static pressure of a liquid head, horizontal spreading would have been observed. Moreover, the maximum radiation readings detected are a very small fraction of the radiation reading in the tank. This is the basis for the conclusion that the rate of leakage and, most likely, the quantity leaked, was small.

Archival records provided a basis for estimating the amount of water added to the tank between 1971 and 1978. Data on heat produced by the sludge were also evaluated and corrected for radioactive decay. The heat required to evaporate the water added to the tank was determined and compared to the heat generated by the sludge. The heat generated in the sludge agrees closely with the amount of heat required to evaporate all the water added to the tank. Hence, the conclusion that nearly all the water was evaporated.

No evidence was found of water intrusions from sources not recorded in the operator's logs. 


\section{TABLE OF CONTENTS}

Page

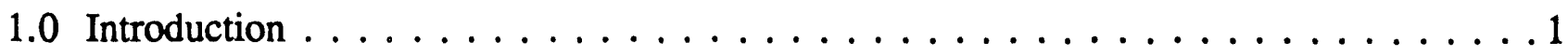

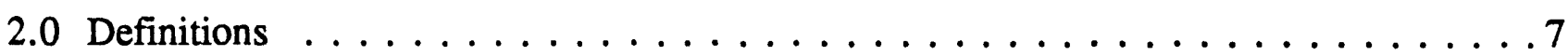

3.0 Other Leak Evaluation Reports $\ldots \ldots \ldots \ldots \ldots$

4.0 Leak Evaluation . . . . . . . . . . . . . . . . . . . . . . 14

4.1 Waste Storage and Transfers, $4 / 62-8 / 68 \ldots \ldots \ldots \ldots \ldots \ldots$

4.2 Pump Down and Sluicing, $8 / 68-11 / 70 \ldots \ldots \ldots \ldots \ldots$

4.3 Temperature Stabilization of Residual Waste

by Cooling Water Additions, $11 / 70-12 / 78 \ldots \ldots \ldots \ldots \ldots \ldots$

4.4 End of Water Additions to Current Date, $12 / 78$ to date . . . . . . . . . 30

4.5 Leakage of Radionuclides . . . . . . . . . . . . . . . . 32

5.0 Concerns Regarding Remediation $\ldots \ldots \ldots \ldots \ldots \ldots \ldots \ldots \ldots \ldots \ldots \ldots \ldots \ldots$

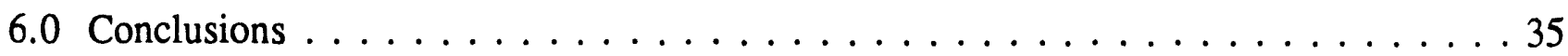

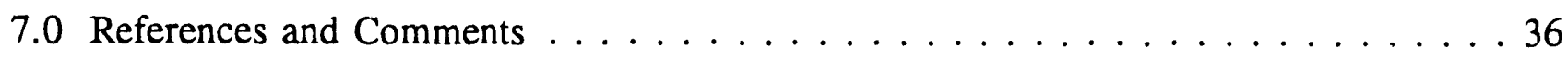

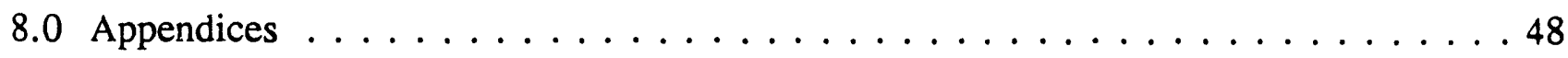

8.1 History of Tank $105-\mathrm{A} \ldots \ldots \ldots \ldots \ldots$

8.2 Water Added to Tank 105-A From $11 / 1 / 73$ through $12 / 4 / 78 \ldots \ldots$. . . . 56

8.3 Bibliography . . . . . . . . . . . . . . . . . . . . . . . 69

8.4 Sludge and Supernate Analyses $\ldots \ldots \ldots \ldots \ldots \ldots \ldots$ 


\section{LIST OF FIGURES}

Page

Figure $1-1 . \quad$ Location of Tank Farm $A \ldots \ldots \ldots \ldots$

Figure 1-2. Typical 241-A Tank Elevation $\ldots \ldots \ldots \ldots \ldots$

Figure 1-3. External Features of Tank $241-A-105 \ldots \ldots \ldots \ldots$

Figure 4-1. Specific Heat Generation Rates Based on Analyses of Tank 241-A-105 Sludge . . . . . . . . . . . . . . . . . 24

Figure 4-2. Heat Required to Evaporate Water vs. Heat Available to Evaporate Water in Tank 241-A-105 . . . . . . . . . . . . . 29

\section{LIST OF TABLES}

Table I. Water Added to Tank 105-A Between

November 1970 and December 4, 1978 . . . . . . . . . . . . . . . 21

Table II. Heat Generated in Tank 105-A and Available for Evaporation . . . . . . . . . . . . . . . 28

Table III. Analyses of Supernate $\ldots \ldots \ldots \ldots \ldots \ldots$ 


\section{TANK 241-A-105 LEAK ASSESSMENT}

\subsection{INTRODUCTION}

This report has been prepared by Ebasco Services Incorporated (Ebasco) as part of WHC Task Order MLW-SVV-037106. The work was performed under Task E-91-10, Environmental/Safety Evaluation of Waste Tank Historical Data, Subtask Tank 241-A-105 (Tank 105-A) Leak Assessment. The intent of the work was to evaluate previous leak estimates for Tank 105-A and to determine if these are accurate based on all available information. Since these estimates ranged from 5,000 gallons to 960,000 gallons, a better estimate is needed to determine what actually took place and to provide a firmer basis for future remediation planning. During the preparation of this report, Ebasco reviewed the contents of 89 boxes of documents from the Federal Records Center in Seattle, Washington. More than fifty documents from the archival boxes and other sources were read and evaluated. These documents are identified in the Bibliography. Principal sources used in the evaluation are the documents listed in Section 7.0, References and Comments.

Tank 105-A is one of 149 single-shell tanks used for storage of highly radioactive waste at the Hanford Site in Washington State. The waste originated from the processing of spent nuclear reactor fuel to recover plutonium for defense purposes.

Tank 105-A was constructed in the early 1950's as one of six one-millon-gallon capacity tanks in Tank Farm A (see Figure 1-1). The tank is constructed of reinforced concrete, with a steel liner on the bottom and up the vertical sides. The footings of the tank are approximately 55 feet below grade. Four temperature laterals (horizontal pipes) are under the tank, located six inches below the footings and about two feet below the concrete tank bottom. There are also three radiation leak detection laterals located approximately 10 feet below the tank bottom, and a number of vertical dry wells in close proximity to the tank; these were added after the tanks were built. Details are shown in Figures 1-2 and 1-3. 


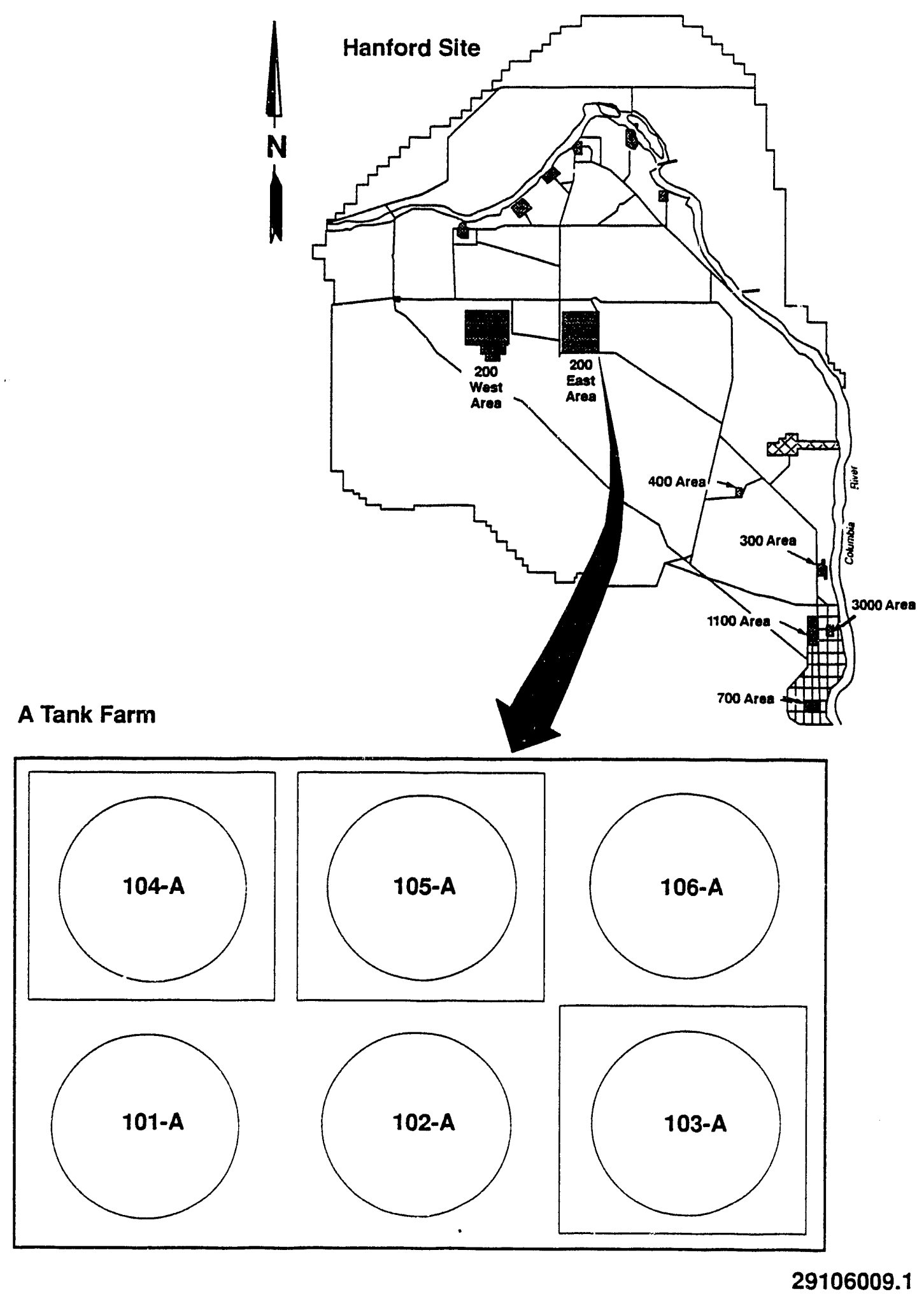

Figure 1-1. Location of Tank Farm 241-A 


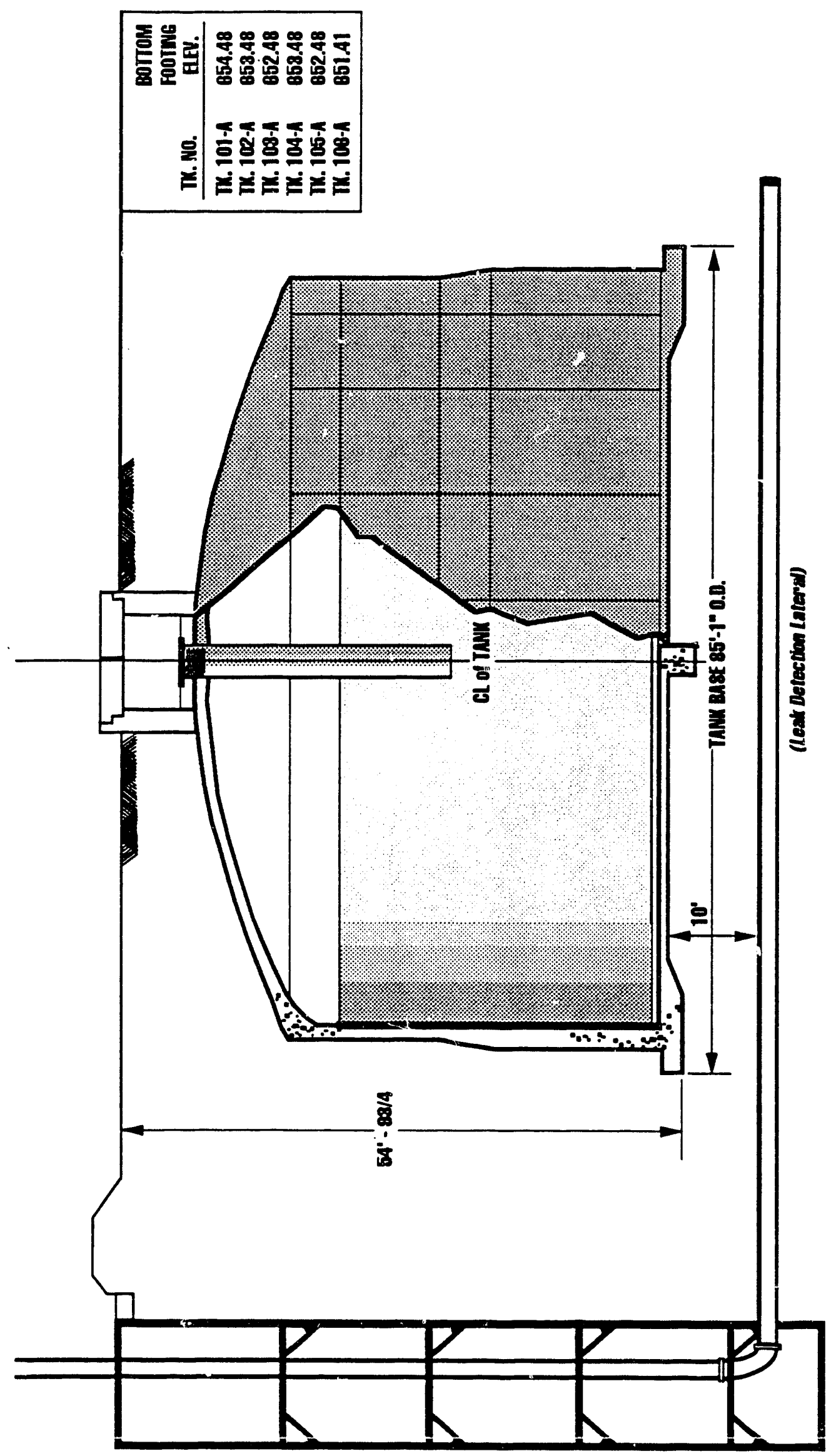

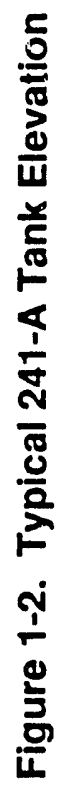




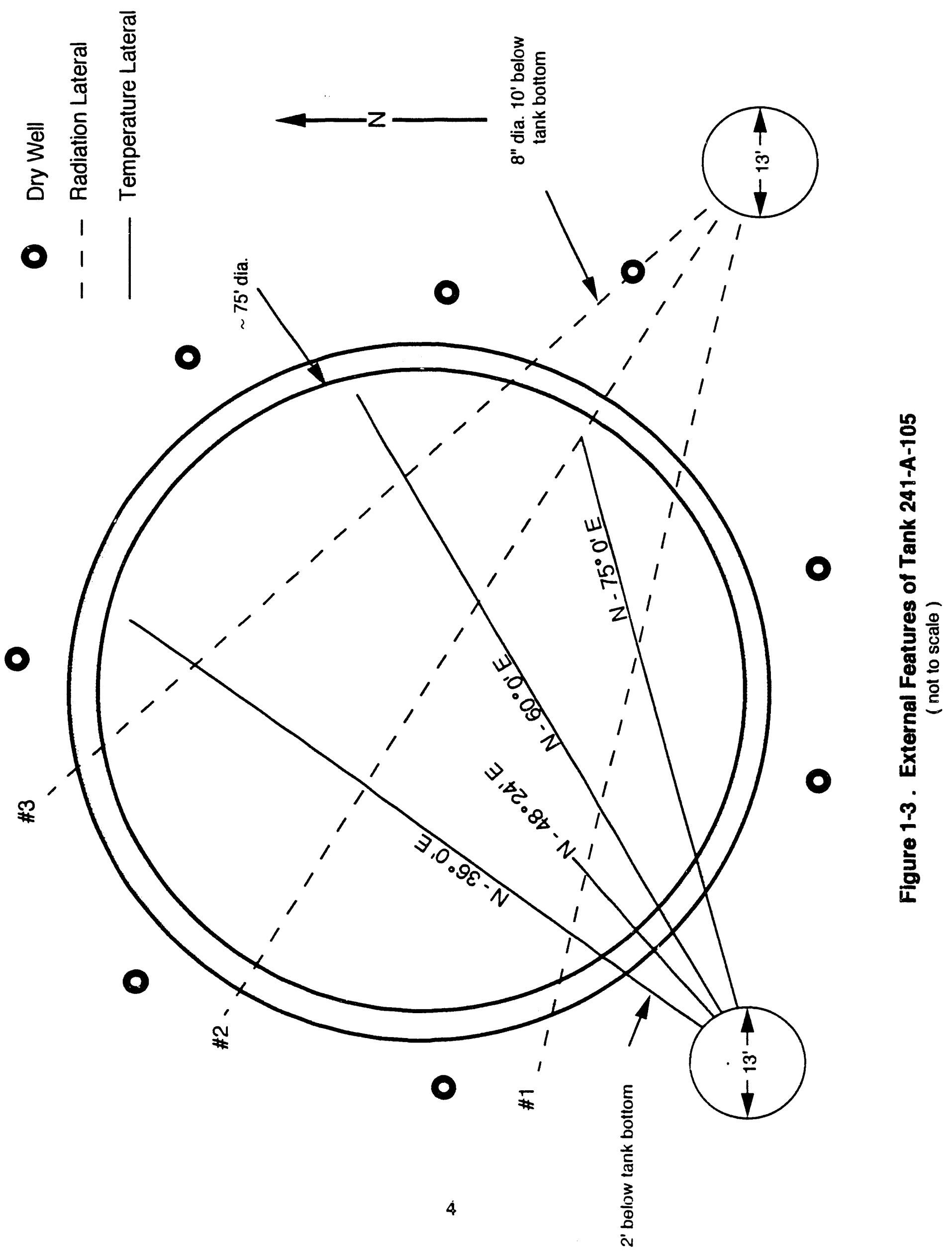


Tank 105-A was selected for the first of a series of leak evaluations 'ecause it was the source of major safety concerns in the past and because large quantities of cooling water were added to the tank after it was established that the tank had leaked. Tank 105-A is unique considering that it released a large amount of steam during a brief period of instability, it has an 80,000 gallon void under a bulge in the mild steel liner which is also ripped open, it was the subject of safety evaluations addressing possible sludge overheating and hydrogen build up, and it had a vent hole chemically milled in the top of the bulged liner bottom to relieve a hypothetical hydrogen accumulation under the bulge.

The evaluation of leakage from Tank 105-A was divided into four time periods consisting of operations (waste storage), removal of waste (sluicing), temperature stabilization of residual waste (cooling water additions), and air cooling. Appendix 8.1 provides a chronology of Tank 105-A activities from 1955 to the present time.

This report analyzes the processes that have been occurring inside Tank 105-A from the point of view of a physical chemist or chemical engineer. The heat balance in the tank has been examined, and conclusions formed as to the likely amount of leakage.

Once a fluid has leaked from the tank, other processes will come into play in the affected area. At least four potentials exist to provide driving forces for these processes. Long time periods are typically available to allow these potentials to effect substantial changes. These potentials are:

1. Gravity

2. Radioactive decay

3. Temperature gradients

4. Transpiration of air

Evaluating the effects of these potentials, and predicting the fate of the material which has escaped from the tank, are outside the scope of this report. However, as an aid to 
understanding and evaluating the observations recorded, a number of factors influencing the transport of liquid through the soil under the tank have been investigated. (Ref. 45, 46)

Well drilling logs (Ref. 46) indicate that the sediments underlying Tank 105-A are highly conductive. That is, a slow leak of clear liquid can percolate downward through the sediments with little horizontal spreading. A flow of this type, directly between the radiation laterals, would show only localized radiation; conceivably, it could be missed completely. What horizontal spreading occurs would be due to capillary action unless the liquid encountered an impervious lay $: r$, at which it would flow horizontally.

If the leak from the tank were large enough to build up a static pressure - that is, if flow due to gravity alone could not move the liquid at the r.ce that it was leaking - the flow would spread horizontally to relieve the pressure. No evidence of this occurring was found in the documentation.

The sorptive capacity of the soil is another consideration in the leak evaluation. Nearly all the radioactive species are absorbed or adsorbed by the soil, shortly after entering it. Ruthenium-106 is the primary mobile radioactive isotope (in relatively new waste) that will move with the moisture front (Ref. 49). Most others will accumulate close to the point of leakage, so long as the leaking fluid remains alkaline.

Yet another characteristic affecting leakage is the filtration ability of the soil. Any solid particles contained in the leaked fluid will be filtered out and, by blocking the flow passages, tend to seal off the leak. 


\subsection{DEFINITIONS}

The tollowing definitions are provided as an aid to understanding terms used in this report.

AIR LIFT - a device for raising liquid by means of compressed air. Compressed air is introduced into the lower end of a vertical pipe, which is submerged in the liquid and open at both ends. The air and liquid mixture, being lighter than liquid alone, rises in the pipe.

AIR SPARGER - a device used to introduce air below the surface of a liquid as small bubbles; essentially a perforated pipe, in many cases.

ARCHIVES - preserved documents from the entire site, stored here in Richland or in the Federal Records Center in Seattle.

CAISSON - a vertical hole of relatively large diameter, lined to prevent cave-ins, and used as a working space to bore horizontal holes under the surface of the earth.

CIRCULATOR - a device installed in a tank to induce movement of liquids and entrainable solids. Circulators in Tank 105-A are of the air-lift type.

CORE DRILLING - the process of boring holes with a device that recovers a continuous core sample of the material through which it passes.

DATA BASE - an accumulation of information on the subject of interest.

INHIBITED SULFURIC ACID - sulfuric acid that contains an inhibitor to minimize or prevent its attacking the steel liner of the tank .

LEAK DETECTION LATERAL - one of three horizontal pipes, located 10 feet beneath the bottom of Tank 105-A, which allow monitoring of radioactivity. 
MAXIMUM ALLOWABLE SALT CONCENTRATION LIMIT - maximum sodium concentration is $7-8$ molar, set by operating procedure to avoid temperature control problems in the sludge layer.

PRIMARY DOCUMENTATION - records consisting of log books, instrument recordings, released drawings and procedures, incident reports, and other real-time documents utilized in the operation and maintenance of the tank farm. Only original documents, signed and dated, were used as "Primary Documentation."

RAW WATER - water which is piped in from outside the tank farm, not the condensate formed by cooling the vapor leaving any of the tanks.

SECONDARY DOCUMENTATION - records consisting of leak-evaluation reports, correspondence, and other summarizing documentation that was generated as part of tank farm operations.

SELF-CONCENTRATION - the process by which the contents of a boiling tank increase in concentration when the water vapor leaving the tank is not condensed and returned to the tank.

SLUDGE - the solid material which settles to the bottom of the tank. It is much more radioactive than is the supernate.

SLUICING - the process of using hydraulic jets to loosen and suspend the settled sludge, then pumping it out of the tank.

SORPTION - a surface phenomenon which may be either absorption or adsorption, or a combination of the two. The term is often used when the specific mechanism is not known. 
SUPERNATE - short for supernatant solution, the liquid contents of a tank from which the solids have settled out to form a sludge layer.

SUPPORTING DOCUMENTATION - any document related to the tank farms that provides ways to increase the reliability of other documentation. Personnel interviews were placed in this category.

TEMPERATURE LATERAL - one of four horizontal pipes, two feet beneath the bottom of Tank 105-A, containing thermocouples to monitor temperatures at these locations.

TEST WELL - a well drilled to confirm conditions suspected or detected by other means, or to explore the extent of those conditions.

WATER HEEL - a low level of water introduced into an empty tank, for a specific purpose, and not pumped out. 


\subsection{OTHER LEAK EVALUATION REPORTS}

Leakage from Tank 105-A prior to the sluicing operations has been estimated or reported by a number of other investigators. Principal among these are the following:

(1) Meeting minutes (Ref. 38) for 11/8/65 state that Battelle Pacific Northwest Laboratories has estimated a leak volume that would produce a temperature increase of $67^{\circ} \mathrm{F}$ over the average background temperature beneath the tank. Depending on the location of the leak relative to the lateral, leak size could be 6,000 to 14,000 gallons. These values assume a hemispherical leak, dry soil, and a soil void fraction of 0.35 .

(2) Meeting minutes (Ref. 38) for $2 / 28 / 66$ state that the Tank 105-A leak is small in volume (less than 50,000 gallons) by comparison with data for tank leaks in the SX Tank Farm.

(3) The Battelle report by Jansen et al. (Ref. 2) analyzes the temperatures in the soil around the tank. From temperature measurements made in the radiation laterals 10 feet below the tank, the leak from Tank 105-A is estimated to be 5,000 to 15,000 gallons.

(4) Reference 39 states that the gallons leaked are "small," and that no data are available on radionuclides that leaked to the soil.

(5) The Final Environmental Statement, ERDA-1538 (Ref. 40), states that the estimated leakage is less than 5,000 gallons.

(6) Reference 42 states that the estimated amount leaked is small.

(7) Reference 43 states that the estimated leak volume is less than 5,000 gallons. 
(8) Reference 44 states that the leak volume previously estimated and reported for Tank 241-A-105 is 5,000 gallons.

(9) Attachment 1 of Reference 23 estimates cooling water leakage at 50,000 to 960,000 gallons. The writer points out that large gaps existed in the data available to him, and that he had not yet made a thorough investigation into the amount of water evaporated.

(10) Reference 50 cites changing radiation profiles in the laterals as a probable indication that a substantial quantity of the water added to the tank was leaking into the soil. The author extrapolates a short-term fluctuation of 13,000 gallons per month to arrive at 1,500,000 gallons over the entire time since the tank was taken out of service. He makes the point that a substantial amount of water may be entering the sediment.

The figure of 1,500,000 gallons is an example of the risk inherent in extrapolating short-term observations over the long term. Based on operator's logs and other observations, the total cooling water added to the tank is estimated at 610,000 gallons, as described in Section 4.3.5.

Reference 50 was not intended to be an accurate estimate of leakage from Tank A-105. The writer used approximate figures to point out that large amounts of water were being added to the tank, then suggested that, as soon as possible, studies should be made to 1) make a mass balance to determine the fate of the water added to the tank, and 2) analyze the sludge in the bottom of the tank to determine the amount of radioactivity being leaked from the sludge.

(11) Reference 51 estimates that 335,000 to 366,500 gallons of water was evaporated from the tank. Combining that number with the 610,000 gallons of 
water added to the tank (from this report). leads to the inference that 244,000 to 275,000 gallons of water leaked to the soil under the tank.

Of the first eight references cited above, only Jansen et al. did the analysis and evaluation required to prepare an independent estimate of leakage; the others cited Jansen's estimate or a modification of it. The ninth and tenth references are not understood as serious estimates of leakage. The final reference is to a current report by Allen (Westinghouse Kanford Co.) which estimates total evaporation during the $1970-1978$ period when cooling vater was being added to the tank.

Jansen et al. analyzed the heat-transfer characteristics of the tank installation, including the surrounding soil, and postulated a number of mechanisms by which hot spots could be created under the tank. Using temperature profiles measured in the radiation laterals 10 feet below the tank, they estimated that in dry soil, the leak volume could be $6,000-14,000$ gallons, depending on the location of the leak relative to the lateral. In wet soil, which has higher thermal conductivity, the minimum hemispherical leak volume would be 18,000 gallons.

In the conclusions of their report, Jansen et al. estimate the leak to be 5,000 to 15,000 gallons, prior to the commencement of sluicing operations.

Allen approached the calculation of water evaporation by a series of computer simulations. The heat generated in the tank was first estimated by adjusting the assumed conditions until the computed results matched the temperature profile observed in the laterals under the tank. This model established the amount of heat removed from the tank through the air ventilation system. A second computer model was then used to calculate the evaporation rate for a range of air flow rates through the tank.

Allen starts with the assumption that only $2,365 \mathrm{ft}^{3}$ of sludge is in the tank, and that none of the sludge is under the bulged bottom of the tank liner. In the process of adjusting the 
computer model to match the temperature in the laterals, he postulated a second, smaller, and homogeneous region of heat generation directly beneath the tank, which seems to require the further assumption that substantial quantities of radionuclides have leaked from the tank. As discussed later in this report, no evidence of such sizable leaks has been found. 


\subsection{LEAK EVALUATION}

This section presents a current evaluation of leakage from Tank 105-A during four phases of the tank's history, including waste storage and transfers, pump-down and sluicing, addition of cooling water, and current conditions.

\subsection{Waste Storage and Transfers, 4/62 - 8/68}

Tank 105-A was built in 1955 but was not used until May 1962, when it was made operational to support the PUREX cesium recovery program. From 1955 to 1962 the tank contained only a water heel ranging in depth to a maximum of 18 inches. In May of 1962, 330,000 gallons of supernate were added followed by a number of transfers of waste into and out of the tank. Heating of the tank was initiated in January 1963 by the addition of thermally hot tank farm condensate in preparation for receipt of PUREX self-boiling waste. After adding the self-boiling waste, the tank reached boiling temperature in early March. While not reported as a problem, it was noted from a review of operational data that unexplained tank level increases as large as 33,000 gallons (12 inches) started to occur as early as September 1963. This indicates that steam was probably forming under the tank liner and deforming it upward at this early date. In one case, following an unexplained rise in the tank level, the data indicated that a drop in level was associated with a temperature drop, further supporting the steam theory.

The first reported leakage problem occurred in November 1963 when low-intensity radiation was detecied in one leak-detection lateral. Reference 3, which reports this incident in detail, indicates the lateral reading was approximately $0.05 \mathrm{R} / \mathrm{h}$ (later corrected to $0.75 \mathrm{R} / \mathrm{h}$ ) compared to a tank internal reading of $40,000 \mathrm{R} / \mathrm{h}$. The tank level had been raised from 260 inches to 280 inches four months earlier. This led to the assumption that the radiation reading in the lateral was due to a side wall leak, so the level was reduced to 260 inches. This action resulted in a slow reduction in radioactivity in the lateral, which led the operators to the conclusion that the leak was indeed in the side wall or was minor and had self-healed. 
This conclusion and the fact that no further storage capacity was available resulted in a decision to maintain the tank at this level. The tank remained in a standby condition until enough water had boiled off to reach the maximum allowable salt concentration limit. At this point, waste was added to the tank to avoid exceeding allowable concentrations.

The tank was then gradually filled with further additions of waste while maintaining the allowable salt concentration and, by October 1964, the level had reached the suspected leak zone with no indication of further leakage. The tank was considered operational and was filled to capacity in December 1964. Tank operation appeared normal and there were no indications of a leak.

The next notable occurrence was a steam release on January 28,1965 . This steam release resulted in the venting of steam through a Tank 103-A riser over a period of approximately 30 minutes. This event created local contamination of soils and equipment around the tank. There was no immediate indication of tank leakage, but 39 days later, on March 8 , increased radiation was detected in Lateral No. 3, which is 10 feet below the tank. The reading in this lateral had decayed to $50,000 \mathrm{c} / \mathrm{m}$ shortly after the November 1963 peak reading and remained constant until March 8, 1905 at which time the reading increased by a factor of 60 and remained constant (see footnote). Test wells were drilled adjacent to the tank and no indication of radioactive contamination was found. One of these wells was drilled to the level of the leak detection laterals and was terminated within 10 feet of the highest radiation reading in the lateral. From this information it was concluded that the leakage from the tank was smiall, as it had not spread horizontally.

While preparing to add an air sparger to the tank to enable mixing the tank contents, workmen encountered an obstruction approximately eight feet above the tank floor. This obstruction had been reported several months earlier, when difficulty was encountered during the use of a sludge probe (Ref. 3). This indicated that the tank floor may have bulged upward prior to the steam release. This indication is further supported by the unexplained increases in tank level observed as early as September 1963 when the tank was first brought Note: Reference 37 questions the factor of 60. 
up to boiling temperature. Investigations (Ref. 3) following the steam release established that the tank floor had bulged upward, creating a void space of approximately 80,000 gallons. After the tank was pumped down for sluicing in 1968, it was established that the liner had ruptured and that the area under the bulge contained a significant amount of sludge. Reference 10 provides full details on the condition of the liner.

Contingency plans and procedures were developed to remove the tank contents, and full sluicing capabilities were installed in the tank. It was then decided (Ref. 3) that the tank would not be emptied until it was scheduled for waste management processing, or until further deterioration was detected.

The tank remained in a static condition until April 1967, when liquid-level fluctuations began to occur. Studies and laboratory tests were performed and, as a result, it was decided that the fluctuations in liquid level were caused by the collapse and regeneration of a steam bubble below the bulged liner. This conclusion was supported by the observation that most of the steam bubble collapses coincided with the addition of cooling water to the tank. This led to the concern (Ref. 3) that a build up of sludge under the bulge would result in elevated temperatures and a potentially unsafe condition.

New areas of low-activity radiation were detected under the tank in mid-1967, indicating that further deterioration of the tank was occurring. Activity in the laterals was, for the most part, directly under the perimeter of the tank. This observation resulted in plans to initiate sluicing activities to remove tank contents. By August 1968, the tank level had been reduced to 35 inches by pumping and the sluicing activities had started.

The cumulative volume of leaks during the operational phase was estimated to be between 5,000 and 15,000 gallons; available data support this estimate. The early leaks appeared to be self-healing. The highest radiation reading 10 feet under the tank prior to March 1965 was $150,000 \mathrm{c} / \mathrm{m}$ (Ref. 3), which roughly translates to $75 \mathrm{mR} / \mathrm{h}$ (Ref. 37); this reading had 
decayed to $50,000 \mathrm{c} / \mathrm{m}$ by March 1965 . The leak triggered by the steam release in January 1965 took 39 days to reach the lateral 10 feet under the tank; this indicates that the leak was small. A major leak should have been detected by significant elevation of temperature readings in the laterals just below the tank bottom. Reference 2 states that a leak of as little as 175 gallons of waste sludge could result in temperatures exceeding $1,500^{\circ} \mathrm{F}$ at the soil/concrete interface. As temperature never exceeded $370^{\circ} \mathrm{F}$, the conclusion that very little sludge leaked out, if any, appears proper. Further support is the fact that the radiation peaks observed did not spread horizontally, as would be expected had the leak been large.

\subsection{Pump Down and Sluicing, 8/68 - 11/70}

Sluicing of Tank 105-A began on August 14, 1968 and was stopped on November 17, 1970, while substantial amounts of sludge remained in the tank. During this period the tank was periodically sprinkled with inhibited sulfuric acid, followed by neutralization, and then sluiced.

At the start of sluicing, Lateral No. 3 (see Figure 1-3) was indicating 200,000 c/m, which reflected a slow decay of radioactivity in this lateral since the 1965 steam release. The peak radioactivity levels in Lateral No. 3 remained constant when sluicing started, but there was an immediate large increase in activity in Lateral No. 2 and a coincident first-time indication of radioactivity in Lateral No. 1. Within three weeks of the start of sluicing, the activity in Lateral No. 1 was holding steady near $35,000 \mathrm{c} / \mathrm{m}$ and the activity in Lateral No. 2 was fairly constant near the $400,000 \mathrm{c} / \mathrm{m}$ reading. A repair of the activity-measuring instrument on October 29 corrected these readings to $20,000 \mathrm{c} / \mathrm{m}, 190,000 \mathrm{c} / \mathrm{m}$ and $120,000 \mathrm{c} / \mathrm{m}$ for Laterals No. 1, 2 and 3 respectively. The sluicing operation clearly caused increased leakage from the tank, probably by loosening and removing solid build-ups at the leak sites.

Although increases in radioactivity in the laterals are said to establish that leakage has occurred, they do not prove that more radionuclides have leaked from the tank. The leakage could be only water. It is well known that most radionuclides are more or less strongly 
absorbed by the alkaline soils of the Hanford area. A leakage of pure water $(\mathrm{pH}=7)$, following the path of an earlier alkaline leak, can mobilize adsorbed radionuclides due to $\mathrm{pH}$ change alone. The mobilized radionuclides, leaked from the tank months or years earlier, could cause observations of increased activity in the laterals. Whether the liquid leaking from the tank is neutral water or supernate cannot be determined from radiation measurements alone, once leakage of radionuclides has occurred.

The next significant change in lateral activity was in August 1970, when all laterals showed increased readings. The reading of Lateral No. 1 increased to $40,000 \mathrm{c} / \mathrm{m}$ and remained constant. Activity in Lateral No. 2 increased to about $375,000 \mathrm{c} / \mathrm{m}$ and fluctuated over a range of $80,000 \mathrm{c} / \mathrm{m}$. Activity in Lateral No. 3 increased to about $960,000 \mathrm{c} / \mathrm{m}$ and varied over a range of $400,000 \mathrm{c} / \mathrm{m}$. These fluctuations indicated that leaks were active and, because the readings remained high, the sluicing operation was aborted on November 17 , 1970. Substantial quantities of sludge remained in the tank, and its heat generation made cooling water additions necessary to maintain safe temperatures.

The volume of leaks which occurred during the sluicing period cannot be estimated from a material balance due to the rapidly changing fluid additions and pump-down rates, but since the radiation zone under the tank remained confined to small areas and did not spread horizontally, it seems likely that large leaks did not occur. Leakage probably exceeded $5,000-15,000$ gallons, but was less than two times that amount, based on the observations made in the laterals.

\subsection{Temperature Stabilization of Residual Waste by Cooling Water Additions, $11 / 70-12 / 78$}

The third historical period of Tank 105-A started in November 1970 when the sluicing operation was completed, and continued until the last water addition was made to the tank on December 4, 1978. During this time, raw water was sprinkled into the tank or was otherwise added into the tank to control temperature rise resulting from radioactive decay of 
radioisotopes in the residual sludge. In this section of the report, one important question is addressed: Of the water that was added into the tank, how much evaporated and how much leaked into the soil under the tank.

The question was approached by examining the heat balance in the tank. An estimate of the amount of water added to the tank was obtained from the original operators' data sheets. The amount of heat generated in the tank was estimated from observations made in Reference 10 of sludge volumes, and isotopic analysis of the sludge was taken from Reference 3. After allowing for heat losses by conduction into the soil, and losses due to heating the ventilation air as it was drawn through the tank, the remainder of the heat generated was available to evaporate water.

\subsubsection{Cooling Water Added}

A measure of the amount of water added to the tank was obtained from three principal sources:

(1) Monthly Boiloff Rates Book for the period ending 3/31/72.

(2) Tank Farm Daily Status Reports for 11/1/73 through 12/4/78.

(3) Tank Farm Liquid Level Readings for 1/1/76 through 12/4/78.

The Daily Status Reports and the Tank Farm Liquid Level Readings are original data recorded by the operators at the time. They are the most reliable data now available, but with one reservation: although water additions are usually recorded in both documents, they are occasionally omitted from one or the other. These records should be examined together, whenever possible, to obtain the most accurate information. Except for the single day, $10 / 31 / 71$, log sheets prior to $11 / 1 / 73$ have not been found.

The Monthly Boiloff Rates Book is the only source of recorded data found for the period $2 / 1 / 71$ through $3 / 31 / 72$. No data were found for water additions from the stopping of 
sluicing on $11 / 17 / 70$ to the start of the Boiloff Rates Book on $2 / 1 / 71$. For the period $4 / 1 / 72$ through 10/31/73, data were found only for June 1973 (Ref. 23); these data appear far too low by comparison with earlier and later water addition rates.

Extracting data from the operators' records is not simply a matter of copying numbers, but is instead a problem of interpretation, of deciding what the entry actually means. Some example entries requiring interpretation are as follows:

(1) "Water added" but no volume stated.

(2) "500 gallons water added" referring to something done and recorded on a previous day.

(3) "Increase in tank level", but no record of water added.

(4) "Water added", but the level did not rise. This is not unusual for small additions of water, as the precision of level readings is about $+/-1 / 4$-inch at best. It could also be that the level was read before the water was added.

(5) Days missing from the records. As only a few days' data were missing, no adjustments were made to compensate for missing days' data.

Water additions to Tank 105-A are summarized in Table I on the following page. The data extracted from the log sheets and used to develop Table I are presented in Appendix 8.2, as are the calculations of average water addition rates and the heat required to evaporate all the water. The water additions preceded by the word "say" in Appendix 8.2 have been inferred from the context, as the amount of water added was not recorded. 
TABLE I.

WATER ADDED TO TANK 105-A

BETWEEN NOVEMBER 1970 AND DECEMBER 4, 1978

\begin{tabular}{|c|c|c|}
\hline TIME PERIOD & $\begin{array}{l}\text { AVERAGE RATE } \\
\text { WATER ADDED } \\
\text { GALLONS/DAY }\end{array}$ & SOURCE OF DATA \\
\hline $\begin{array}{c}11 / 1970 \text { to } \\
1 / 31 / 71\end{array}$ & ---- & None Found \\
\hline $2 / 1 / 71$ to $3 / 31 / 72$ & 290 & Boiloff Book (Ref.1) \\
\hline $\begin{array}{l}4 / 1 / 72 \text { to } \\
10 / 31 / 73\end{array}$ & ---- & None Found \\
\hline $\begin{array}{l}11 / 1 / 73 \text { to } \\
12 / 31 / 74\end{array}$ & $242^{(1)}$ & Daily Status Reports \\
\hline 1975 & $221^{(1)}$ & $\begin{array}{l}\text { Tank Farm Status Report } \\
\text { (Box 58071, Archives) }\end{array}$ \\
\hline 1976 & 159 & $\begin{array}{l}\text { Tank Farm Status Report } \\
\text { and Liquid Level Readings } \\
\text { (Box 58073, Archives) }\end{array}$ \\
\hline 1977 & 141 & $\begin{array}{l}\text { Tank Farm Status Report } \\
\text { and Liquid Level Readings } \\
\text { (Box } 61285 \text {, Archives) }\end{array}$ \\
\hline $1 / 1 / 78$ to $12 / 4 / 78$ & 121 & $\begin{array}{l}\text { Tank Farm Status Report } \\
\text { and Liquid Level Readings } \\
\text { (Box 68653, Archives) }\end{array}$ \\
\hline
\end{tabular}

NOTES: (1) Water introduced by flushing circulators is assumed to be 180 gallons per occurrence during these time periods. 
A significant amount of water was added to the tank through flushing the circulators, which is required to maintain them in operating condition and thereby ensure continuous operation (Ref. 25). The amount of water so added was not recorded by the operators; only a notation that this event had occurred. This was done daily in February 1971, and an amount of 180 gallons per day is included in the water additions recorded in the Boiloff Book (Ref.1). A flushing rate of $15 \mathrm{gpm}$ for three minutes for each of four circulators equates to 180 gallons, per a notation in the book. Although the flushing was said to have been stopped in early 1971, the Tank Farm 241-A Status Reports show that circulators were flushed frequently until the end of August 1975. A water addition of 180 gallons/occurrence was assumed for the period of $11 / 1 / 73$ through $8 / 31 / 75$.

In all the documentation examined, no evidence was found of significant water intrusions from sources not recorded in the operator's log sheets. Water was routinely added through the sprinkler head and the volume faithfully recorded, except for the few occasions noted in Appendix 8.2. Circulators were flushed and so noted in the log sheets. On a few other occasions, when for some reason the sprinkler could not be used, water was introduced to the tank via another path; in all cases, the volume of water added appears to have been recorded in the log sheets.

Where data are not available, and where interpretation is required, thinking and engineering judgment have been strongly influenced by standard operating procedures and other instructions (Refs. 24, 25, 26, and 27). From these water addition data, and heat release considerations, a total water addition of approximately 610,000 gallons is inferred. See Section 4.3.5. 


\subsubsection{Heat Generated}

The amount of heat generated in Tank 105-A at any time is the product of two factors: 1) the specific rate of heat generation per cubic foot of residual solids, and 2) the volume of solids remaining in the tank. All available earlier documents on the subject have been reviewed. These are listed in the References, Section 7.0.

For this heat balance analysis the first factor was calculated from available analyses of sludge samples, plus heat generation rate and decay calculations. For the second factor the estimates of Woodward-Clyde (Ref. 10), which were developed from stereoscopic photographs of the tank's interior and other measurements, were accepted. Substantial uncertainties are present in both factors, as will be discussed later in this section.

Three samples of the sludge were taken from different locations in the tank and analyzed in January 1972 (Ref. 4). The necessary calculations were made to determine heat generation rates during the 1971-1978 period. Using the same terminology as the reference document, these are identified as curves one- $a$, one-c, and two-b on the Specific Heat Generation Rates curves on the following page. The average of these analyses is also plotted as curve ave-72. Note that the heat generation rates for these samples vary by a factor of 3.6. In reporting these analytical results, the authors of Ref. 4 point out two anomalies in the data: The duplicate analyses are in good agreement for the non-radioactive constituents, but vary substantially for the radioactive species; and the particle densities reported for the "dry" solids were substantially less than those reported for other sludges, and appear to be in error.

An earlier sample of the sludge was analyzed in 1965 (Ref. 3). Similar calculations were made from this analysis, resulting in curve sixty-five of the Specific Heat Generation Rates curves. This curve falls within the range of the three 1972 analyses, and is lower than the average of those analyses by a factor of 1.5 . 


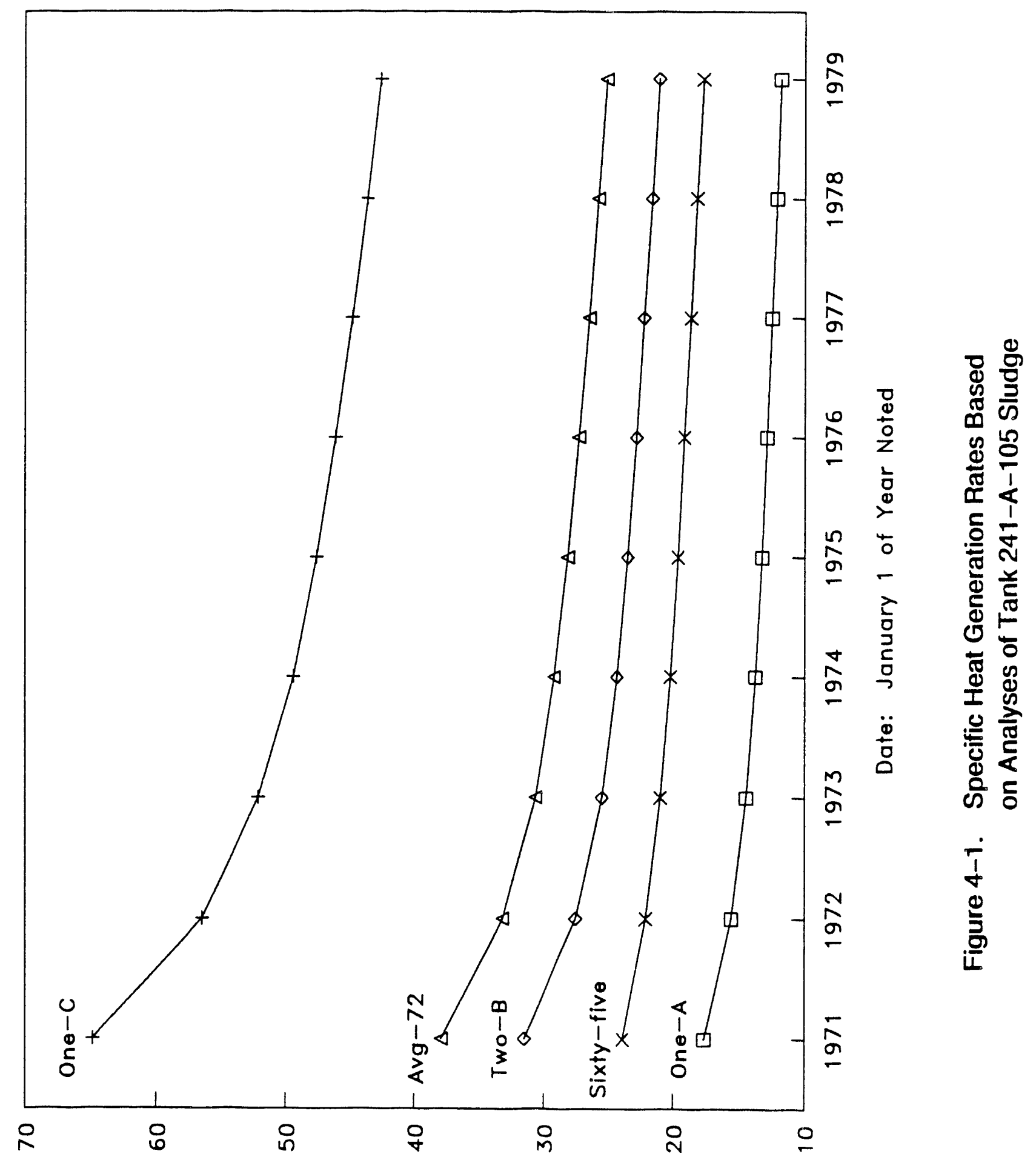

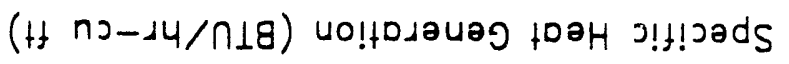


Earlier documentation contains references to a calorimetric determination of heat generation and to a 1978 isotopic analysis, but neither of these nor confirmation that they exist have been found.

The 1965 analysis has been adopted as the basis for heat release calculations. It is lower than the average of the 1972 analyses, and more conservative so far as calculations of cooling water leakage are concerned. The data are taken from Reference 3 and are presented in Appendix 8.4.

The volume of sludge in the tank has been reported several times (References 5, 9, 10, 11, and 14). Woodward-Clyde (Ref. 10) approached the estimate directly by photographic observation of the tank interior, using stereo photos and other physical measurements of the tank and its contents to prepare topographic maps of the bottom contours of the tank. They estimated the amount of sludge remaining in the tank, and prepared profiles to illustrate the conditions assumed in making the estimate. Commenting on the results of their study, the authors state that "...they are subjective and are based on judgments as well as hard data."

Everly and Bath (Ref. 11) estimated the sludge in the tank through a computer simulation to match a given temperature profile in the temperature laterals under the tank. A key factor in their calculations was a specific heat generation rate of $29.47 \mathrm{Btu} / \mathrm{hr}^{-\mathrm{ft}^{3}}$, which appears to have come from the 1972 sludge analyses (Ref. 6). Everly and Bath do not comment on the computer program they used; it is not clear whether it can be used to estimate sludge quantities which are not in direct contact with the bottom of the tank. The Woodward-Clyde report suggests that sizable amounts of sludge may be in such positions.

Woodward-Clyde concluded that sludge remaining in the tank was in three positions:

(1) between the bulged and ruptured liner and the wall of the tank: $1,000-1,200 \mathrm{ft}^{3}$

(2) on top of the liner: $1,300-1,600 \mathrm{ft}^{3}$, and

(3) under the bulged liner: choose $A: 2,000-2,500 \mathrm{ft}^{3}$

or B: $4,000 \mathrm{ft}^{3}$ 
For estimating the heat generation in the tank this report uses numbers at the low end of the Woodward-Clyde estimates. It uses the sum of the smallest volumes shown above, or 4,300 $\mathrm{ft}^{3}$, as the estimated sludge volume. This is again conservative, for purposes of estimating cooling water leakage.

\subsubsection{Heat Transfer by Ventilation}

One approach to estimating the heat release in the tank is to measure the ventilation air flow, its temperatures into and out of the tank, and the relative humidities into and out of the tank, from which the increase in enthalpy is a straightforward calculation. Campbell (Ref. 14) took this approach and calculated a heat release of $60,000+1-40,000 \mathrm{Btu} / \mathrm{hr}$.

For this report, water evaporation and dry air heating are handled as separate items in the enthalpy calculations. This is an equally valid approach, and for this report it is more practical. Water additions can be measured directly and, theoretically at least, with excellent accuracy. Air heating is handled as a reduction in the heat available for evaporation, and if this is small, large uncertainties can be accepted without affecting the validity of the conclusions.

Air flow through the tank was not metered during this period. Kaser and Veneziano (Ref. 8) estimate the flow at $150-660 \mathrm{ft}^{3} / \mathrm{min}$, "...with the most likely value being in the lower end of that range." Their upper-level estimate of $660 \mathrm{ft}^{3} / \mathrm{min}$ is based on the assumption that the air flow from each tank is equal. The lower estimate takes into account the actual operating conditions in the plant in June 1976, recognizing that the tanks in A, AX, AY and AZ farms all operate at different levels of negative pressure. This report accepts Kaser and Veneziano's comment that the most likely value is at the lower end of the range, and uses $150 \mathrm{ft}^{3} / \mathrm{min}$ for estimating heat losses to tank ventilation.

Using a tank outlet air temperature of $115^{\circ} \mathrm{F}$ and an inlet air temperature of $48^{\circ} \mathrm{F}$ (both from Ref. 22), the temperature rise is $67^{\circ} \mathrm{F}$ as the air passes through the tank. Heat 
absorbed by the $150 \mathrm{ft}^{3} / \mathrm{min}$ of inlet air is estimated at $11,900 \mathrm{Btu} / \mathrm{hr}$. This heat is not available to evaporate water.

\subsubsection{Other Heat Losses}

Other heat losses will, like the loss to dry air, reduce the amount of heat available to evaporate water. One such loss is the loss by conduction - upward through the dome, and downward through the tank bottom.

Jansen (Ref. 2), in 1965, estimated heat losses by conduction to be $16,700 \mathrm{Btu} / \mathrm{hr}$ through . the ground surface and 2,140 Btu/hr downward to the water table, assuming dry soil. His calculations were for a tank full of liquid and sludge, at a temperature of $226^{\circ} \mathrm{F}$ near the dome and near $230^{\circ} \mathrm{F}$ at the tank bottom. His teruperature at the surface of the soil above the dome is $70^{\circ} \mathrm{F}$, and his temperature at the water table, 201 feet below the surface, is also $70^{\circ} \mathrm{F}$.

For the 1971-1978 time period, the tank bottom temperature may be assumed to be $230^{\circ} \mathrm{F}$, but the vapor space temperature will be close to $115^{\circ} \mathrm{F}$ (Ref. 22). Adjusting approximately for these changed conditions, the following heat losses by conduction are estimated:

Downward to the water table:

Upward through the ground surface:

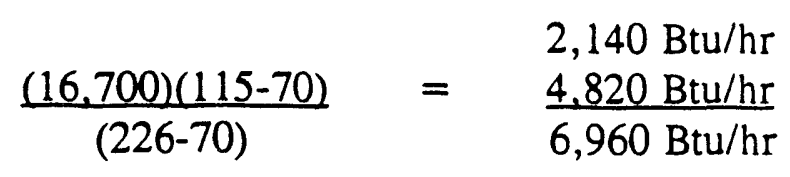

This heat also is not available to evaporate water. Total heat losses, therefore, are approximately $18,900 \mathrm{Btu} / \mathrm{hr}$.

\subsubsection{Heat Discussion}

The amount of water added to Tank 105-A during this period is known, and the amount of heat required to evaporate all this water can be calculated. The rate at which heat was 
generated in the tank by radioactive decay is known, and allowances can be made for known heat losses; the remaining heat was available for the evaporation of water. From a comparison of these heat balance items, it may be judged whether leakage from the tank was essentially nil, modest, or excessive in amount.

Heat available for evaporating water, after allowing for air heating and conduction losses, was as follows:

TABLE II. HEAT GENERATED IN TANK 105-A AND AVAILABLE FOR EVAPORATION

\begin{tabular}{||c|c|c|c||}
\hline DATE & $\begin{array}{c}\text { SPECIFIC } \\
\text { HEAT } \\
\text { GENERATION } \\
\text { Btu/hr-ft }\end{array}$ & $\begin{array}{c}\text { TOTAL HEAT } \\
\text { GENERATION } \\
\text { Btu/hr }\end{array}$ & $\begin{array}{c}\text { HEAT } \\
\text { AVAILABLE } \\
\text { FOR } \\
\text { EVAPORATION } \\
\text { Btu/hr }\end{array}$ \\
\hline $1-1-71$ & 23.9 & 102,600 & 83,700 \\
\hline $1-1-72$ & 22.1 & 94,900 & 76,000 \\
\hline $1-1-73$ & 21.0 & 90,200 & 71,300 \\
\hline $1-1-74$ & 20.2 & 86,900 & 68,000 \\
\hline $1-1-75$ & 19.6 & 84,300 & 65,400 \\
\hline $1-1-76$ & 19.1 & 82,000 & 63,100 \\
\hline $1-1-77$ & 18.6 & 79,900 & 61,000 \\
\hline $1-1-78$ & 18.1 & 77,900 & 59,000 \\
\hline $1-1-79$ & 17.7 & 75,900 & 57,000 \\
\hline
\end{tabular}

The above information is shown on the following page in a graph showing three plots: 1) a bar chart showing how much heat would be required to evaporate all the water added to Tank 105-A, 2) a curve showing heat available for evaporation, based on the 1965 sludge 


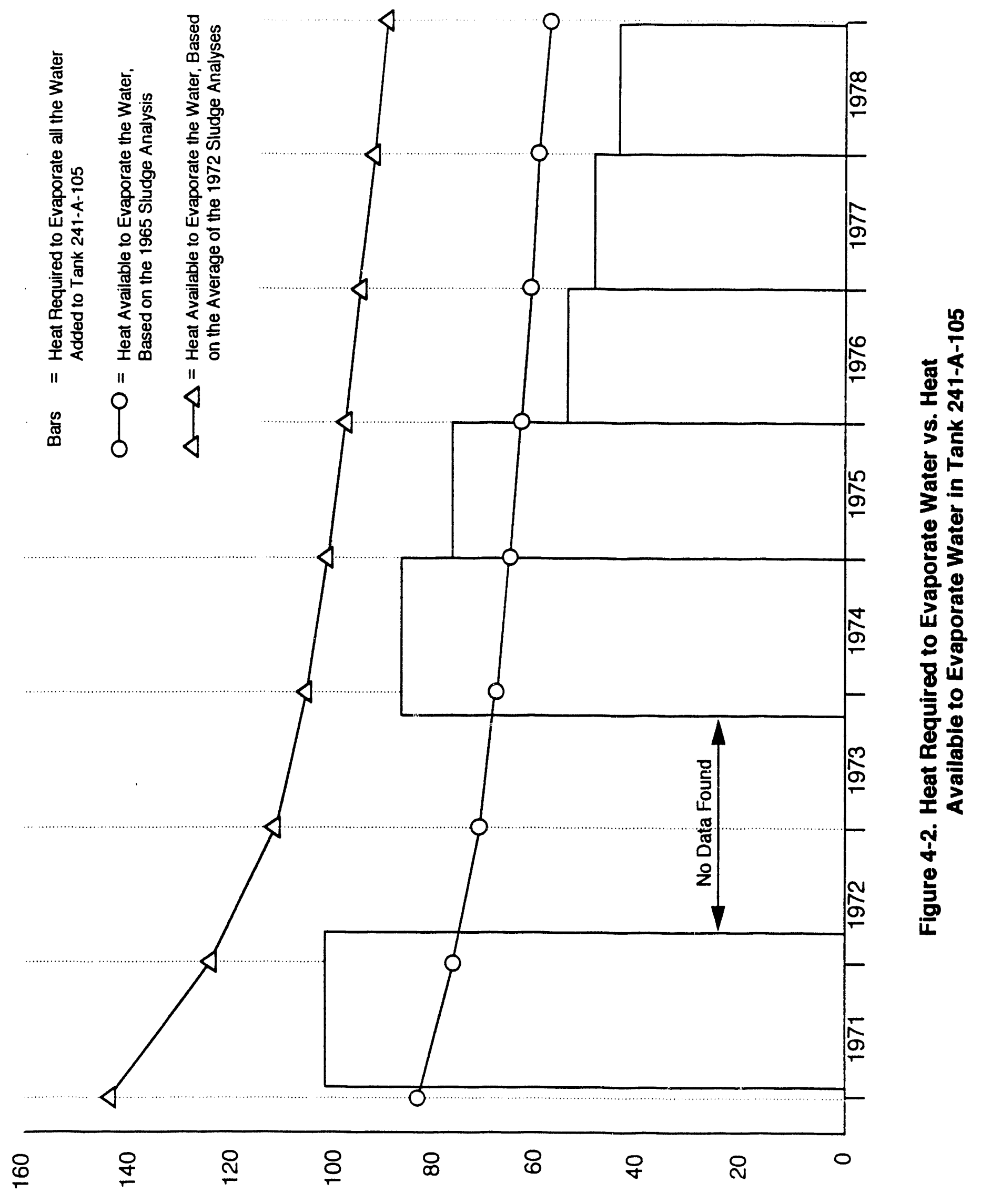

ก 18 jo spuesnou - je日H 
analysis, from the above table, and 3) a second curve showing heat available for evaporation, based on the average of the three 1972 analyses.

From this heat balance plot and other knowledge of the history of the tank, two significant observations are made: 1) The heat available in the tank was approximately that required to evaporate all the water added. During the period 4/1/72 through $10 / 31 / 73$, for which no data were found, the operating procedures were identical to those used during earlier and later periods (Ref. 24, 28). That is, the tank level was held essentially constant and only enough water was added to do so. It is reasonable to assume that water additions during the period of missing data would fall in line with the other periods. On this assumption, total water additions to the tank are estimated at approximately 610,000 gallons. 2) If a fair line were drawn through the tops of the bars denoting heat required, it would have a slope steeper than that of the heat available curve. No explanation is available for the different slopes, but this could happen if the 1965 sludge analysis failed to report significant amounts of short. lived radionuclides. Exploring this possibility, it appears that this may indeed be the case. The 1972 analyses, for example, report the presence of Sb-125 and Eu-154 (Ref. 4). Jungfleisch (Ref. 15) suggests that a number of other radionuclides may be present in significant amounts.

From other operating data found in the archives it is known that some leakage occurred during 1975 , as increased activity was detected in the radiation laterals under the tank at that time. No basis for estimating the volume of these leaks has been found, but all indications are that the leakage was small.

\subsection{End of Water Additions to Current Date, 12/78 to date}

A review of temperature readings and radiation readings for Tank 105-A confirmed that the radioactivity has decayed substantially and that temperature readings are constant. As an example, the peak count in any of the three radiation laterals, since late 1985, has been 268 $\mathrm{c} / \mathrm{s}$ in Lateral No. 1, 2,000 c/s in Lateral No. 2, and 7,000 c/s in Lateral No. 3. The peak 
readings are still centered in the previous leak locations and have shown very little variance for the past six years.

On June 12,1990 , there was a one-day peak reading of $23,070 \mathrm{c} / \mathrm{s}$, which, when checked the next day, had changed to $433 \mathrm{c} / \mathrm{s}$. It is suspected that this was caused by a radioactive gas build-up in the lateral or other spurious reason and was not an indication of leak activity.

The highest temperature reading below the tank in April 1991 was $220^{\circ} \mathrm{F}$ and temperatures were tairly consistent across the tank bottom. Dry well radiation readings, taken from early 1991 records, indicate that all of these readings have decayed to or near background.

Air cooling of the residual sludge in the tank is continuing and periodic radiation and temperature readings are being taken in the tank, in the laterals below the tank, and in the drywells surrounding the tank.

Psychrometric survey data taken since January 1979 suggest that substantial amounts of water continue to evaporate from Tank 105-A. The cumulative amount evaporated between January 1979 and December 1990 would be about 40 feet of water, if these data are to be believed. This is clearly unlikely, unless water additions to the tank have been resumed, as the tank level at the beginning of the period was less than eighteen inches.

Ebasco has not explored the reason for this apparent anomaly, as it is beyond the scope of this sub-task. Three avenues of exploration should be considered:

1. The methods used, while fully adequate for tank monitoring, may not be of sufficient accuracy for water-loss calculations.

2. The data were all obtained on the day shift; 24-hour monitoring may reveal a reversal of equilibrium conditions in the tank. 
3. Perhaps soil moisture is being drawn into the tank and contributing to the humidity measured in the exhaust air. A pressure gradient exists for such a flow, and a possible chimney effect should not be overlooked.

\subsection{Leakage of Radionuclides}

The number of curies of radioactivity accumulated under Tank 105-A because of leakage from the tank has been estimated. From the earlier observations of the self-plugging nature of the leaks, it appears likely that little if any of the solid sludge materials escaped from the tank. The basis for the estimate is the supernate analysis obtained on May 1, 1965 (Ref. 3), and presented in Appendix 8.4, with appropriate decay calculations applied to arrive at a 1/1/91 analysis. These analyses are as follows:

TABLE III. ANALYSIS OF SUPERNATE

\begin{tabular}{|c|c|c|}
\hline Component & $\begin{array}{c}\text { Analysis May 1, 1965 } \\
\text { Curies/gal }\end{array}$ & $\begin{array}{c}\text { Decayed to Jan. 1, 1991 } \\
\text { Curies/gal }\end{array}$ \\
\hline $\mathrm{Sr}-90$ & 0.034 & 0.018 \\
\hline $\mathrm{Ce}-144$ & $<0.019$ & $<2.4 \times 10^{-12}$ \\
\hline $\mathrm{Cs}-137$ & 30.7 & 16.9 \\
\hline $\mathrm{Ru}-106$ & $<0.076$ & $<1.4 \times 10^{-9}$ \\
\hline $\mathrm{ZrNb}-95$ & $<0.019$ & 0 \\
\hline
\end{tabular}

During the operational phase the fluid leaked is assumed to be supernate. During the sluicing phase the fluid leaked could have ranged from water at one extreme, to supernate at the other. This gives a basis for estimating the range of curies that may have leaked during these periods. 
After the sluicing had been completed and cooling water was being added, the situation is not so clear. The amount of leakage is unknown and cannot be estimated, but is thought to be small. The sludge remaining in the tank has been leached with sulfuric acid and with large amounts of water; most likely, the solids remaining are essentially insoluble in water with a radioisotope content that is only a small fraction of that in the original supernate. Leakage during this period is probably water.

Based on the above considerations and the range of leakage estimated in this report, from 85,000 to 760,000 curies have accumulated under Tank $105-\mathrm{A}$. Of this, about $99.9 \%$ is from Cs-137, and $0.1 \%$ from Sr-90. Other constituents reported in the 1965 analysis of supernate have decayed away to insignificance. 


\subsection{CONCERNS REGARDING REMEDIATION}

Although the amount of material leaking from Tank 105-A was probably relatively small, the depth of penetration into the soil under the tank cannot be determined from existing data. From 1) the observed radiation peaks, 2) the fact that these peaks are directly under the tank walls, 3) the limited horizontal spreading of the radioactive areas, and 4) the known characteristics of the soil, it is likely that the leaks followed narrow paths downward. The depth of penetration, and therefore the magnitude of the remediation problem, can best be determined by a program of core drilling at an angle under the tank.

Another unknown that will enter into plans for remediation is the amount of sludge remaining in the tank, in particular the unseen sludge under the bulge in the liner. The WoodwardClyde report estimates this unseen amount at 2,000-4,000 $\mathrm{ft}^{3}$ If it becomes necessary to know this amount more accurately, some direct method of measurement would be preferred over any indirect method.

Although the Allen report (Ref. 51) and this work differ by up to 244,000 gallons in the amount of water leaked during the sprinkling phase, they represent a considerable narrowing of the 5,000 to 960,000 gallons estimated by earlier investigators. In that sense, they may be said to be roughly in agreement. The major value of these reports, however, is any guidance they may provide for remediation planning. As applied to that problem they are in complete agreement: core drilling under the tank is advisable, to define the limits of contamination. 


\subsection{CONCLUSIONS}

From the analysis of data from Tank 105-A, the following conclusions regarding leakage from the tank can be drawn:

(1) The extent of leakage during the operational phase (prior to 8/68) was estimated at that time to be between 5,000 and 15,000 gallons. This earlier estimate was reasonable.

(2) During the sluicing phase (8/68 - 11/70), leakage exceeded 5,000 to 15,000 gallons, but probably did not exceed twice that amount. Insufficient data are available to be more precise. Estimated leakage during this phase is therefore 5,000 to 30,000 gallons.

(3) While cooling water was being added to the tank (11/70 - 12/78), the procedures followed by the operators of the tank farm were intended to control temperatures, while minimizing the amount of leakage into the soil under the tank. They effectively achieved these goals.

(4) Between 2/1/71 and 12/4/78, approximately 610,000 gallons of cooling water were added to Tank 105-A. Most, and perhaps nearly all, of this water was evaporated.

(5) Radionuclides escaping into the soil under the tank cannot be estimated directly because of many uncertainties. Based on a range of total leakage from 10,000 to 45,000 gallons, assumed compositions, and decayed to $1 / 1 / 91$, radioactivity under the tank is expected to be in the range of $85,000-760,000$ curies. Of this, $99.9 \%$ is from Cs-137, 0.1\% from Sr-90. 


\subsection{REFERENCES AND COMMENTS}

1. Monthly Boiloff Rates, June $\mathbf{1 9 6 5}$ to March 1972, ARHCO internal memos with calculation sheets attached. These show boiloff rates while the tank was full, and after sluicing had been completed. In many months the boiloff was calculated, but not reported in the memo. Basic assumption in all cases is that all water put into the tank was evaporated, after allowing for net level change during the month.

2. 12/22/65 (approx.), Report by G. Jansen, Jr., et al., Techniques for Calculating Tank Temperatures and Soil Temperatures Near Leaks - Application to PUREX Waste Tank 105-A, BNWL-CC-376. This study applies to a condition in which Tank 105-A is full of liquid and sludge, boiling, and uniformly hot as a result. It contains the following information which is germane.

The volume of the leak from Tank 105-A is estimated at 5,000 to 15,000 gallons. In dry soil, about $16,700 \mathrm{Btu} / \mathrm{hr}$ is lost upward to the ground surface and about 2,140 Btu/hr downward to the water table. For wet soil these increase to 66,100 and 9,300 $\mathrm{Btu} / \mathrm{hr}$ respectively; the temperature distribution remains unchanged.

Air flowing at $100 \mathrm{ft}^{3} / \mathrm{min}$ could remove $23,000 \mathrm{Btu} / \mathrm{hr}$. (NOTE: Exit air at $230^{\circ} \mathrm{F}$.)

${ }^{95} \mathrm{Zr}-\mathrm{Nb}$ and ${ }^{144} \mathrm{Ce}$ are present only in the sludge in alkaline tanks and in solution in acid tanks.

3. 10/31/67, Report by S.J. Beard, et al., PUREX TK-105-A wiaste Storage Tank Liner Instability and Its Implications on Waste Containment and Control, ARH-78. See pg. 18 of this reference for 5/1/65 analysis of separated sludge taken from Tank 105-A. Heat release calculated from this analysis falls within the range of the samples taken on $1 / 1 / 72$. 
4. 1/12/72, Letter, W.W. Schulz/C.W. Hobbick to C.J. Francis/C.M. Walker, Composition and Density of the 105-A Solids. Reports the analyses of two dry solids and one slurry sample, taken from different locations in Tank 105-A. The letter notes that the analyses of inert ingredients are in good agreement for the three samples, but that there is substantial difference in the radioactive elements. This anomaly is not explained.

NOTE: Heat release calculations for the analyses vary from 15.5 to 56.4

$\mathrm{Btu} / \mathrm{hr}-\mathrm{ft}^{3}$. The arithmetic mean is $33.15 \mathrm{Btu} / \mathrm{hr}-\mathrm{ft}^{3}$. Samples were analyzed in early January, 1972.

5. 7/31/74, Report by W.P. Metz, Action Plan for Stabilizing Tank 241-A-105, ARH-CD-135. States that as much as $2,005 \mathrm{ft}^{3}$ of sludge may be under the bulged liner. Further states that radiolytic heat generation rate has been determined both by isotopic and calorimetric analysis, and that the two methods agree at 34-42 Btu/hr- $\mathrm{ft}^{3}$.

The report also states (pg. 4) that 2,000 gallons/week of water are required to hold an 18-inch level in the tank, leading to the conclusion that 1) heat release is about $100,000 \mathrm{Btu} / \mathrm{hr}$ or that 2) the tank leaks. However, routine leak detection monitoring has not detected leaks.

NOTE: We have been unable to find a calorimetric determination of heat generation rate. Water addition data from other sources indicates that water addition rate at this time was about 1700 gallons/week. Our calculations from chemical analyses give an average heat release for the three samples of 33.15 $\mathrm{Btu} / \mathrm{hr}^{-\mathrm{ft}^{3}}$ in January 1972. Decayed to 1974 , we calculate $29.15 \mathrm{Btu} / \mathrm{hr}^{-\mathrm{ft}^{3}}$. 
6. 2/12/76, Letter, S.S. Koegler to R.E. Felt, $\underline{A}$ and AX Tank Sludge Heat

Generation Rates. Cites the average heat generation rate of three sludge sam-les from Tank 105-A, based on content of ${ }^{90} \mathrm{Sr}$ and ${ }^{137} \mathrm{Cs}$ only, at $3.94 \mathrm{Btu} / \mathrm{hr}$-gal. Notes that the samples varied by a factor of 3 , and that the samples were obtained in 1972 .

NOTE: $(7.48)(3.94)=29.47 \mathrm{Btu} / \mathrm{hr}-\mathrm{ft}^{3}$. This is the source of the heat release number used in later studies.

Calculations by Frank Young (Ebasco), which take into account all the radioactive species reported, give a heat generation rate of $33.15 \mathrm{Btu} / \mathrm{hr}-\mathrm{ft}^{3}$ for early 1972 , higher than the rate reported by Koegler.

7. 12/19/77, Letter, J.H. Roecker to O.J. Elgert, Program Plan for Stabilization of Tank 105-A, 9606R-2. Contains the following statements in an attachment:

Heat loss to ground from tank at $140^{\circ} \mathrm{F}=16,000 \mathrm{Btu} / \mathrm{hr}$.

Heat loss due to water evaporation and ventilation $=17,200 \mathrm{Btu} / \mathrm{hr}$ approx.

Heat losses for tank at $180^{\circ} \mathrm{F}$ at 500 SCFM and $60 \% \mathrm{RH}=240,000 \mathrm{Btu} / \mathrm{hr}$.

This attachment is not referred to in the body of the letter. The attachment refers to reference (c), while the letter has only references (a) and (b).

NOTE: We conclude that this attachment is misplaced and does not pertain to Tank 105-A.

8. 1/23/78, Report by J.D. Kaser and T.B. Veneziano, Tank 105-A Stabilization Progress Report, RHO-CD-255. Contains the following statement on page 31:

Over the past year, water has been added at an average rate of 1,000 gallons per week. If all of this water is evaporated by 
radioactive decay heat, the corresponding heat generation rate would be about $50,000 \mathrm{Btu} / \mathrm{hr}$.

NOTE: This may be the source of the $1,000 \mathrm{gal} / \mathrm{wk}, 50,000 \mathrm{Btu} / \mathrm{hr}$ figures cited frequently in later documents. To check: water addition from liquid level readings is $141 \mathrm{gal} / \mathrm{d}$, or $987 \mathrm{gal} / \mathrm{wk}$.

$$
(141)(8.35)(1 / 24)(1,000)=49,100 \mathrm{Btu} / \mathrm{hr}
$$

The report also notes that the tank ventilation rate is about $150 \mathrm{ft}^{3} / \mathrm{min}$. This, plus heat loss to the ground, would consume at least part of the excess heat from radioactive decay.

9. 2/1/78, Letter, Roecker to Elgert, Decision to Measure Hydrogen Concentration in Tank 105-A Before Performing Drving Tests, 9606-R3. Contains the statement "...Woodward-Clyde Consultants have estimated that there may be $2,800 \mathrm{ft}^{3}$ of sludge under the liner."

NOTE: This appears to be preliminary information, which was expanded by Woodward-Clyde in their formal report.

10. 3/24/78, Report by Woodward-Clyde Consultants, An Estimate of Bottom Topography, Volume and Other Conditions in Tank 105-A, Hanford.

Washington. The volume of sludge between the bulged and ripped liner and the wall of the tank is $1,000-1,200 \mathrm{ft}^{3}$. The volume of sludge on the liner was calculated to be $1,563 \mathrm{ft}^{3}\left(1,300-1,600 \mathrm{ft}^{3}\right)$.

Two estimates are made for the volume of sludge under the liner: 1) $2,000-2,500 \mathrm{ft}^{3}$, and 2) $4,000 \mathrm{ft}^{3}$. 
The report further states, on pages 14 and 15 , that unseen sludge under the liner controls the temperatures observed in the laterals under the tank.

11. 8/10/78, Letter, Everly/Bath to Veneziano, Heat Transfer Study on Tank 105-A, 60414-78-051. Based on data from Tank Farm Process Engineering, estimates 2,365 $\mathrm{ft}^{3}$ of sludge in the tank. Heat generation rate of $29.47 \mathrm{Btu} / \mathrm{hr}-\mathrm{ft}^{3}$ was provided by Tank Farm Process Engineering. $(2,365)(29.47)=69,700 \mathrm{Btu} / \mathrm{hr}$ heat generated in 1978.

12. 11/21/78, Letter, Everly to Veneziano, Transient Heat Transfer Study on Tank 105-A, 60413-78-0132. Based on the same data as the 8/10/78 study, finds that 1,195 SCFM of air is required to remove heat from Tank 105-A. Recommends that measures be taken to prevent short-circuiting of air flow in the tank.

13. March 1980, Report by Robert J. Catlin, Assessment of the Surveillance Program of the High-Level Waste Storage Tanks at Hanford. Table 20 on page 84 states an estimated heat generation rate of $60,000+/-30,000 \mathrm{Btu} / \mathrm{hr}$, but provides no data or source for the figures. The table is referred to on pg. 64 of the report, but no further information given. The tank is said to contain $4,400 \mathrm{ft}^{3}$ of solids.

Page 115 states: "Past unplanned releases to soil are not known; owing to the philosophy of using soil as a secondary containment, spills and other accidental releases within the tank farm boundaries were not recorded routinely until 1972."

Appendix $\mathrm{H}$ states that the maximum leak undetectable by the dry well monitoring is 17,500 gallons; by the horizontal laterals, 5,000 gallons.

14. October 1981, Report by G.D. Campbell, Heat Transfer Analysis for In situ Disposal of Nuclear Wastes in Single- and Double-Shell Underground Storage 
Tanks, RHO-LD-171 Informal Report. Used psychometric data to calculate a heat release of $60,000+1-40,000 \mathrm{Btu} / \mathrm{hr}$ in Tank 105-A. States that heat loss by conduction was estimated, but gives no figures. Sludge volume stated is $2,500 \mathrm{ft}^{3}$, no source given.

15. March 1984, Report by F.M. Jungfleisch, Preliminary Estimation of the Waste Inventories in Hanford Tanks Through 1980, SD-WM-TI-057. Reports a heat generation rate of $12,000 \mathrm{Btu} / \mathrm{hr}$ in Tank 105-A.

NOTE: This is much lower than found in other sources.

16. 7/23/86, Rockwell Internal Letter, W.S. Lewis/A.T. Alstad to S.J. Joncus, Replacement of Defective Thermocouples in Single-Wall Tanks, 65950-86-437. States that Tank 105-A heat load is $18,000 \mathrm{Btu} / \mathrm{hr}$ "from attached graph", but no graph is attached.

NOTE: This heat load is not supported by other documents.

17. 9/30/88, Waste Storage Tank Status and Leak Detection Criteria, by R.K. Welty, SD-WM-TI-356. This states (pg. 10-05-13) a heat release of 38-42 Btu/hr- $\mathrm{ft}^{3}$ for an $84,000 \mathrm{Btu} / \mathrm{hr}$ heat generation rate. Water required is $2,000 \mathrm{gal} / \mathrm{wk}$ which corresponds to $100,000 \mathrm{Btu} / \mathrm{hr}$.

NOTE: The information cited here appears to have been taken from an earlier report by Metz. See Ref. 5 above. This heat release is substantially higher than that found in other sources.

18. 4/20/89, Memo, R.D. Gibby to V.D. Maupin, High Heat Single-Shell Tanks, 13316-89-0042. Cites heat generation rates taken from the above sources and "decayed to 1989." 


$\begin{array}{ll}50,000 \mathrm{Btu} / \mathrm{hr} & \text { Ref. } 14 \\ 49,000 \mathrm{Btu} / \mathrm{hr} & \text { Ref. } 13 \\ 17,000 \mathrm{Btu} / \mathrm{hr} & \text { Ref. } 16 \\ 11,000 \mathrm{Btu} / \mathrm{hr} & \text { Ref. } 15 \\ 39,000 \mathrm{Btu} / \mathrm{hr} & \text { Average of first three }\end{array}$

Gibby eliminated the $11,000 \mathrm{Btu} / \mathrm{hr}$ figure from his average for two reasons: 1) the theoretical nature of Ref. 15 as compared to the empirical nature of the other sources, and 2) the heat release stated in Ref. 15 showed a significant statistical difference from the other values for Tank 105-A.

NOTE: Until support for the $17,000 \mathrm{Btu} / \mathrm{hr}$ figure can be found, we would eliminate this figure as well.

19. 3/28/90, Report, T.W. Fisher/W.W. Chen/R.B. Pan, Thermal Analysis of SingleShell Tank A-105, WHC-SD-WM-DA-061 Rev.0. Uses a heat rate of 50,000 Btu/hr taken from Gibby to Maupin memo dated 4/20/89, above.

NOTE: Why did Fisher et al. not use 49,000 or 17,000 or $39,000 \mathrm{Btu} / \mathrm{hr}$, which were also reported by Gibby? To be conservative we presume. Fisher et al. used solid thermal conductivity of $0.25 \mathrm{Btu} / \mathrm{hr}-\mathrm{ft}-{ }^{\circ} \mathrm{F}$. Lange's handbook gives 0.080 for dry soil, 0.23 for dry sand. Presumably, Fisher et al. assumed some level of water in the soil.

20. 10/9/90, Engineering Data Transmittal, M.D. Britton to R.E. Raymond, Heat Balance Calculations, WHC-CM-3-4. Calculates an average heat release in Tank 105-A of 78,500 Btu/hr for the 1971-78 period while cooling water was being sprinkled into the tank. All is based on a specific heat release of $29.47 \mathrm{Btu} / \mathrm{hr}-\mathrm{ft}^{3}$, taken from Ref. 12 above, and used without considering radioactive decay from 1972 to 1978 . 
21. 3/7/91, Calculations by F.J. Young of Ebasco, Heat Generation from Sludge Analyses. Not issued. Based on the three analyses reported in Ref. 4, one analysis in Ref. 3 and the table Radionuclide Specific Activity and Heat Generation, heat generation rates were calculated for four analyses decayed to 1972. Results:

\begin{tabular}{|c|c|c|}
\hline 72 & $1^{2}$ & $15.52 \mathrm{Btu} / \mathrm{hr}^{-\mathrm{ft}^{3}}$ \\
\hline & & $56.41 \mathrm{I}$ \\
\hline & & $27.53 \mathrm{Btu} / \mathrm{hr}^{-\mathrm{ft}^{3}}$ \\
\hline & & $\begin{array}{l}33.16 \\
22.06\end{array}$ \\
\hline
\end{tabular}

Counting ${ }^{90} \mathrm{Sr}$ and ${ }^{137} \mathrm{Cs}$ only, for the 1972 samples, average heat release is 29.62 $\mathrm{Btu} / \mathrm{hr}-\mathrm{ft}^{3}$, which agrees closely with the $29.47 \mathrm{Btu} / \mathrm{hr}-\mathrm{ft}^{3}$ figure in Ref. 6 .

22. 10/8/90, M.D. Britton calculations, 105-A Heat Balance, Evaporation, EDT \#125702. Calculations are based on the use of 1972 analytical data for a 1978 heat release calculation, without considering radioactive decay from 1972 to 1978 . See Ref. 20.

23. 10/26/90, Letter, W.H. Hamilton, Jr. to R.E. Gerton, Single-Shell Tank 241-A105 Leak Volume Estimate, 8901832B R2. Good source of information and reference to documentation. Estimates cooling water leakage at $50,000 \mathrm{gal}$ to 960,000 gal.

24. 4/26/71, ARHCO memo, C.M. Walker and G.C. Oberg to L.W. Roddy, Process Limits and Waste Disposal in A, AX, and AY Farm Tanks. Instructs that for Tank 105-A, level is to be maintained between 28 and 31 inches, except as required for sluicing. Circulators 2 and 4 are to be set at $10 \mathrm{ft}^{3} / \mathrm{min}, 1$ and 3 at $0 \mathrm{ft}^{3} / \mathrm{min}$. 
25. 7/8/64, Report by L.W. Roddy and B.V. Snow, Operation of a Boiling-Waste Tank Farm, HW-83215. To ensire continuous agitation, the circulators are waterflushed daily and diluent-flushed every month.

26. SOP 200.2.28, In-Tank Sprinkling. States that water is sprinkled in 500-gallon batches, not to exceed 1,000 gallons per week.

27. SOP TO-020-320, In-Tank Sprinkling, replaces SOP \#200.2.28, released 11/2/78. States that water is sprinkled 500 gallons at a time, not to exceed 1,000 gallons per week.

28. 9/30/76, Occurrence Report 76-124, Maximum Liquid Level Limit Exceeded. States that the operating and specification limits specify an operating range of 18 to 20 inches.

29. 5/26/78, Occurrence Report 78-49, Radiation Peak Increase in 105-A Lateral 1405-03 Exceeding Increase Criteria. Cites water spill on 2-23-78 as a possible cause of increased activity observed in laterals under Tank 105-A.

30. 8/25/70, ARHCO Memo, C.M. Walker and W.C. Schmidt to L.W. Roddy, Process Limits and Waste Disposal in A and AX Farm Tanks. Tank 105-A level to be maintained at 30-32 inches.

31. 6/2/70, ARHCO memo, C.M. Walker and W.C. Schmidt to L.W. Roddy, Process Limits and Waste Disposal in A and AX Farm Tanks. Tank 105-A liquid level to be maintained at 28-31 inches, except as required for sluicing. Circulators 2 and 4 set at $10 \mathrm{ft}^{3} / \mathrm{min}, 1$ and 3 at $0 \mathrm{ft}^{3} / \mathrm{min}$. 
32. 3/13/78, Letter, R.C. Routson and J.B. Sisson to E.H. Carbaugh, Raw Water Leak in 241-A Tank Farm on February 23-24, 1978. Leak was from a broken pipe. Approximately 60,000 gallons infiltrated into the soil.

33. 2/23/78, Occurrence Report 78-24, Release of Raw Water in 241-A Tank Farm. Rupture of M5a line released approximately 60,000 gal of water, causing a cave-in between Tank 102-A and Tank 105-A.

34. 1/3/90, WHC Internal Memo 13314-89-132, D.A. Reynolds to R.E. Raymond, Temperature Rise in Laterals Under 241-A-105. Temperatures have increased due to shutdown of the portable exhauster in Spring 1989. Prompt repair of the exhauster is recommended.

35. 10/8/90, WHC Internal Memo, W.H. Hamilton Jr. to distribution, October 5 Tank 105A Meeting. Contains comments contributing to recent history of Tank 105-A.

36. 4/30/91, Personal Communication, V.D. Maupin. Penetration of the bulge in Tank 105-A was completed on October 7, 1978.

37. 8/5/77, Letter, J.H. Roecker to O.J. Elgert, re: Ref. 3 above, R77-99. This questions certain data presented in Reference 3, but is not completely clear as to what the correct data should be.

38. 2/3/65 through 5/16/66, Meeting Minutes re: Bumping of Tank 241-A-105, various authors (Archives Box No. G 85617). Good information on observations and investigations made at the time. 
39. 1/30/74, Letter, M.C. Fraser and D.J. Larkin to H.P. Shaw, Radionuclide Inventories in Leaks from Transfer Lines and Tanks. States that no data are available.

40. December 1975, Final Environmental Statement. Waste Management Operations, Hanford Reservation, ERDA-1538. This copy is not complete. Good general information on the site.

41. June 1983, K.S. Murthy et al., Assessment of Single-Shell Tank Residual Liquid Issues at Hanford Site, Washington, PNL-4688 UC-70. Estimated leakage from Tank 105-A is less than 5,000 gallons. States that Ru is not absorbed in the soil, but moves with the leaked water.

42. 10/9/84, Report by D.C. McCann and T.S. Vail, Waste Status Summary, September 1984, RHO-RE-SR-14 September 1984. States that the estimated amount leaked from Tank 105-A is small.

43. 8/17/88, WHC Internal Memo, C.M. Walker to G.L. Dunford, Summary of Leaker or Questionable Integrity Tanks, 13331-88-460. States that less than 5,000 gallons have leaked from Tank 105-A.

44. 5/17/89, Letter, R.J. Baumhardt to R.E. Gerton, Single-Shell Tank Leak Volumes, 8901832B R1. Leakage previously reported from Tank 105-A is 5,000 gallons.

45. June 1979, A.M. Tallman et al., Geology of the Separation Areas, Hanford Site, South-Central Washington, RHO-ST-23, Rockwell Hanford Operations, Richland, Washington. Reports the general geology of the Separations Area and defines in detail the geologic environment of the local site (241-A Tank Farm). 
46. April 1976, W.H. Price, and K.R. Fecht, Geology of the 241-A Tank Farm, ARH-LD-127, Atlantic Richfield Hanford Company, Richland, Washington. Reports the generalized geology underlying the 241-A Tank Farm.

47. 10/30/90, Electronic Mail Message, Rick Raymond to Distribution, Fact Sheet on Tank A-105 Temperatures. Contains contributions to recent history of Tank 105-A.

48. 10/29/90, Electronic Mail Message, E.J. Campbell to R.E. Raymond, RTQ, Tank 105-A. Describes current status of Tank 105-A.

49. December 1981, Report by R.E. Isaacson and K.A. Gasper, A Scientific Basis for Establishing Dry Well-Monitoring Frequencies, RHO-ST-34. Excellent report, describing behavior of subsurface plumes.

50. 4/12/78, Letter, R.C. Routson to S.P. Stalos, Changing Radiation Profiles in 105A Lateral Dry Wells Since November 1977, and Letter to E.H. Carbaugh on Raw Water Leak in 241-A Tank Farm on February 23-24, 1978, 60110-78-003. States that 5,000 gallons per month of water is being added to the tank, and suggests that as much as 570,000 gallons may have leaked to the soil. Recommends 1) a mass balance of the fate of the water entering the tank and 2) analysis of the sludge and a determination of the amount of radioactivity being leached.

51. June 1991, Report by G.K. Allen, Tank 241-A-105 Evaporation Estimate 1970 through 1978, WHC-EP-0410. Undergoing the approval process as this is written, this report postulates heat generation in $2,365 \mathrm{ft}^{3}$ of sludge in the tank, and further heat generation in the soil under the tank. For $150 \mathrm{ft}^{3} / \mathrm{min}$ air flow through the tank, estimated evaporation is 366,501 gallons. 


\subsection{APPENDICES}

8.1 History of Tank 105-A

8.2 Water Added to Tank 105-A from 11/01/73 through 12/04/78

8.3 Bibliography 


\subsection{History of Tank 105-A}

\section{Operating Phase}

1955 Tank 105-A was built and placed in reserve status, containing a six-inch water heel. (Ref. 3)

$5 / 1962$ Water depth has increased to 18 inches, due to addition of water to vapor seals. (Ref. 3)

5/1962 Pumped 330,000 gal. of supernate from Tank 103-A to Tank 105-A over a period of 20 days. Average rate $16,500 \mathrm{gal} /$ day. Temperature increased from $46^{\circ}$ to $56^{\circ} \mathrm{C}$. (Ref. 3)

7/27/62 Transferred 180,000 gal. from Tank 103-A. Temperature in Tank 105-A went up $8^{\circ} \mathrm{C}$. (Ref. 3)

7/27/62 Removed 63,000 gal. of supernate from Tank 105-A for cesium recovery in PUREX. (Ref. 3)

12/12/62 Pumped 252,000 gal. from Tank 101-A into Tank 105-A. Temperature in Tank 105-A went up $14^{\circ} \mathrm{C}$. (Ref. 3)

12/1962 Blended Tank 105-A with the air-lift circulators. Transferred 490,000 gal. of supernate to Tank 103-C. Pumped remainder of Tank 105-A into Tank 101A, leaving 10-inch heel in Tank 105-A. (Ref. 3)

1/1963 Started preparing Tank 105-A for full radiation level PUREX waste storage. Added 330,000 gal. of thermally hot tank farm condensate. Heated tank from $50{ }^{\circ} \mathrm{C}$ to $62{ }^{\circ} \mathrm{C}$. (Ref. 3)

1/1963 Added full radiation level PUREX waste to bring tank up to boiling temperature. (Ref. 3)

3/5/63 Continued filling of Tank 105-A per routine, with no problems. (Ref. 3)

7/1963 Tank liquid level reached 280 inches. (Ref. 3) 
$9 / 25 / 63$

and

others

11/19/63 Tank 105-A about half-full. Radiation detected in one lateral, indicating a tank leak. A leak in the side wall was postulated as a possibility so the tank liquid level was reduced by self-concentration to 260 inches. A slow decline of the radiation intensity in the lateral indicated the leak had stopped either because of self-sealing or because the liquid level was below the leak point. (Ref. 3)

$12 / 1963$ to $9 / 1 / 64$

$10 / 1964$

$12 / 1964$

$1 / 28 / 65$

$3 / 1965$

$3 / 8 / 65$

After

$3 / 8 / 65$

$4 / 1965$
Held tank level 2.: 260 inches until the salt concentration operating limit was reached. Starte $\perp$ increasing liquid level. (Ref. 3)

Reached the postulated leak level, with no evidence of any new leakage. (Ref. 3)

Tank 105-A is filled to capacity. (Ref. 3)

Sudden steam release occurred in Tank 105-A. Steam vented from riser on Tank 103-A for about 30 minutes. No wastes were added to Tank 105-A on this day except for tank farm condensate. Inspection confirmed damage to structure of tank and its internals. (Ref. 3)

Intensity of radiation in the leak detection lateral has decayed by a factor of 3 , to approx. $50,000 \mathrm{c} / \mathrm{m}$. (Ref. 3)

Radiation in \#3 lateral increased to about $195,000 \mathrm{c} / \mathrm{m}$, then remained constant. No radiation increases were detected in the other laterals or the vertical wells. (Ref. 3, 37)

Three test wells were drilled along the side of the tank, directly over the lateral that indicated leakage. No radioactive contamination was detected in the soil removed from these wells, and maximum temperature in the test wells

Temperature of $325^{\circ} \mathrm{F}$ found in Lateral \#3, about $90 \mathrm{ft}$ horizontally from the caisson. Temperature was monitored, and by June 1966 had dropped to about $220^{\circ} \mathrm{F}$, which was slightly warmer than Laterals $\# 1$ and $\# 2$. (Ref. 3,37 ) was $206^{\circ} \mathrm{F}$. These data indicated the leakage was small. (Ref. 3) 
Late 1965 Conclusions reached: (Ref. 3)

1. Tank had ceased to leak

2. Leakage was small - no significant contamination of atmosphere or groundwater.

3. Tank liner was bulged upward, creating an 80,000-gal. void space under the liner.

4. It is unlikely that sludge is in the void.

5. Need to vent the bulged area.

6. The probability of sludge leaks into the soil is low.

7. Leakage of supernate would not cause high temperatures.

8. Dryout of the sludge might allow temperatures to go to $10,000^{\circ} \mathrm{F}$ or higher.

9. Overheated sludge would produce $\mathrm{NO}_{2}$ gas and fission products.

10. An atmospheric release would be more hazardous than a release to the soil, due to the sorption capacity of the soil.

11. Potential hazards will decrease as time passes, due to decay.

11/1965 Full sluicing capability was in place. (Ref. 3)

Fall Decision made to maintain Tank 105-A in a static condition until scheduled for 1965 waste management processing, or until finding evidence of further tank deterioration. (Ref. 3)

4/1967 Cyclic liquid level variation began to occur. Level dropped 9-10 inches in minutes, stayed stable for 20 hours, returned to original level in about a day. (Ref. 3)

10/2/67 Low-level radiation detected in \#2 leak detection lateral. Heat generation rate has decreased by a factor of 4 since the steam release event. Plans and preparations for sluicing are under way. (Ref. 3)

10/31/67 Hazards analysis shows that the risks of high waste temperatures are far greater than the risks of water going into the soil, even assuming gross leakage of wastes. (Ref. 3)

8/1968 Reduced liquid level from the operational level of 142 inches to 35 inches. (Ref. 8) 
OPERATIONAL PHASE

TO AUGUST 13, 1968

\section{Sluicing Phase}

8/14/68 Sluicing of the sludge within the tank began. (Ref. 8)

11/6/69 Water level 31.5 inches. (Ref. 10)

6/2/70 Tank 105-A liquid level to be maintained at 30-32 inches, except as required for sluicing. (Ref. 31)

8/25/70 Tank 105-A liquid level to be maintained at 30-32 inches, except as required for sluicing. All liquid transfer routings have been removed from Tank $105-$ A; liquid level maintained through use of a Rainbird sprinkler. (Ref. 30)

9/9/70 Water level 24 inches. Sluicing is under way. (Ref. 10)

11/17/70 Sluicing of the tank was stopped. (Ref. 8)

11/25/70 Water level 26 inches. Much sludge has been removed since Sept. 9 photos. (Ref. 10)

\section{Cooling Water Additions}

11/1970 Liquid level was held between 34 and 38 inches. (Ref. 8)

to

$11 / 24 / 71$

2/1971 Water addition to tank was 750 gallons per day. (Ref. 23)

through

$4 / 1971$

2/1971 Added $180 \mathrm{gal} /$ day circulator flush water. (Ref. 23)

4/26/71 Tank 105-A liquid level to be maintained at 28-31 inches, except as required for sluicing. Liquid level maintained through use of a Rainbird sprinkler.

(Ref. 24) 
5/1971

through

$3 / 1972$

11/24/71 Liquid level was allowed to decrease to 13.5 inches. (Ref. 8)

12/1971 Liquid level was not recorded, but is assumed that the level was maintained and

$1 / 1972$

1/27/72 Level was brought up to 19 inches. (Ref. 8)

1/1972 Tank level was held at or near 16 inches. (Ref. 23)

to

$8 / 1973$

1/27/72 Liquid level allowed to slowly drop to 15 inches. (Ref. 8)

to

$9 / 13 / 73$

$4 / 1972$

to

$6 / 1973$

9/1973

to

$10 / 1973$

10/26/73 Brought liquid level up to 18 inches. Maintained level by water additions at 17.25 to 18.5 inches until January 1978. (Ref. 8)

8/4/75 A flush valve was inadvertently left open and the level of the tank went up to 23.75 inches. No water was added to the tank again until September 11 , 1975, when the level had again returned to 18 inches. (Ref. 8)

About Water is being added through an impulse sprinkler in Riser R-8. The water is $1 / 1976$ added in 500 to 1,000 gallon increments approximately seven times each month. Over the past year, water has been added at an average rate of 1,000 gallons per week. If all this water is evaporated by radioactive decay heat, the corresponding heat generation rate would be about 50,000 Btu per hour. (Ref. 8) 
10/7/76 Color photos difficult to interpret. Water level 17.5 inches. (Ref. 10)

12/1977 Woodward-Clyde completed stereo photography interpretation of the ruptured tank bottom. Events of the "bump" appear to have occurred in this sequence: (Ref. 10)

1) Steam pressure underneath buckled the tank floor upwards.

2) Steel of the wall was bent upward, and the edge of the liner was bent downward.

3) Then, the $90^{\circ}$ floor-to-wall weld ripped.

2/23/78 Approximately 60,000 gallons of uncontaminated water was spilled to the ground in the 241-A tank farm and infiltrated into the soil. Scintillation probes which measure total gamma activity indicated that some radionuclide movement took place to the depth of the laterals adjacent to tanks 106-A and 103-A tank, thus indicating that the wetting front advanced to at least 60 feet below the ground surface. (Ref. 32)

Apparent cause of the 60,000 gallon water release was the rupture of the M5 a line about 30 feet southeast of the 501 Building. The water channeled from the site of rupture, along a pipe encasement, to the area of cave-in between Tanks 102-A and 105-A. (Ref. 33)

5/8/78 Radiation peak in lateral 14-05-03 increased from 8,600 counts per second to

to 18,000 counts per second on 5/15/78. Possible causes being investigated:

$5 / 15 / 78$ 1) water being added to tank to control temperature, and 2) water spilled to the ground on 2/23/78 east of 241-A Tank Farm. (Ref. 29)

10/7/78 The bulged tank bottom was penetrated, using a chemical milling procedure, and the gas trapped beneath the bulge was sampled. (Ref. 36)

10/7/78 Tests for hydrogen gas beneath the bulged bottom were completed, and no hydrogen was found. (Ref. 23)

12/4/78 Last water addition to the tank. (Ref. 23) 


\section{Current Phase}

3/1979 The tank is interim stabilized. (Ref. 35)

10/1985 The tank is interim isolated. (Ref. 35)

4/1/89 Shut P-17 exhauster down due to high HEPA inlet temperature. Highest temperature in \#3 Lateral is $240^{\circ} \mathrm{F}$. (Ref. 47)

11/27/89 The hottest point under Tank 105-A has reached a temperature of $290{ }^{\circ} \mathrm{F}$. (Ref. 34)

3/17/90 The exhauster was restarted. Temperature under Tank $105-\mathrm{A}$ is $308^{\circ} \mathrm{F}$. (Ref. 48)

$8 / 20 / 90$ The exhauster was shut down. Temperature under the tank was $270{ }^{\circ} \mathrm{F}$. (Ref. 48)

9/30/90 Restarted exhauster. (Ref. 47) 
8.2 Water Added to Tank 105-A from 11/1/73 through 12/4/78 
WATER ADDED TO TANK 105-A

FROM 11/1/73 THROUGH 12/31/74

Source: $\quad$ Tank Farm - 241A Status Report (TRAC 0058, TRAC 0059)

Status Report - 241A Tank Farm (TRAC 0059)

\begin{tabular}{|c|c|c|c|c|c|}
\hline DATE & $\begin{array}{l}\text { GALLONS } \\
\text { SPRINKLED }\end{array}$ & $\begin{array}{l}\text { CIRCLLATORS } \\
\text { FLUSHED }\end{array}$ & DATE & $\begin{array}{l}\text { GALLONS } \\
\text { SPRINKLED }\end{array}$ & $\begin{array}{l}\text { CIRCULATORS } \\
\text { FLUSHED }\end{array}$ \\
\hline Nov.1 & 500 & & Dec. 20 & 250 & \\
\hline 2 & & $\mathbf{X}$ & 21 & 250 & $\mathrm{X}$ \\
\hline 4 & & $\mathbf{X}$ & 24 & 250 & $\mathrm{X}$ \\
\hline 5 & 500 & $\mathbf{X}$ & 25 & & $x$ \\
\hline 6 & 500 & & 26 & 250 & $\mathrm{X}$ \\
\hline 7 & 500 & $\mathbf{X}$ & 27 & 500 & \\
\hline 8 & 500 & & 28 & 250 & $\mathrm{X}$ \\
\hline 9 & 250 & $\mathrm{X}$ & 31 & 500 & $x$ \\
\hline 12 & 500 & $x$ & Jan. 2 & 250 & $x$ \\
\hline 13 & 500 & & 3 & 250 & \\
\hline 14 & 250 & $\mathbf{X}$ & 4 & 250 & $X$ \\
\hline 15 & 250 & & 7 & 500 & \\
\hline 16 & 250 & $\mathrm{X}$ & 8 & 400 & \\
\hline 19 & 500 & $x$ & 9 & 250 & $x$ \\
\hline 20 & 250 & & 10 & 250 & $x$ \\
\hline 21 & 250 & $x$ & 11 & 250 & $X$ \\
\hline 22 & 250 & & 14 & 250 & $\mathrm{X}$ \\
\hline 23 & 251 & $\mathbf{X}$ & 15 & 250 & \\
\hline 27 & 250 & & 16 & 250 & $x$ \\
\hline 28 & 240 & $\mathrm{X}$ & 17 & 250 & \\
\hline 29 & 250 & & 18 & 250 & \\
\hline 30 & 250 & $x$ & 21 & 250 & \\
\hline Dec. 1 & & $\mathrm{X}$ & 22 & 250 & \\
\hline 4 & 250 & & 23 & 250 & $x$ \\
\hline 5 & 250 & $x$ & 24 & Say 250 & \\
\hline 6 & 250 & & 25 & 250 & $X$ \\
\hline 7 & 250 & $\mathbf{X}$ & 28 & 250 & \\
\hline 10 & 500 & $\mathrm{X}$ & 29 & 250 & \\
\hline 11 & 250 & & 30 & 250 & $\mathrm{x}$ \\
\hline 12 & 250 & $X$ & 31 & 250 & \\
\hline 13 & 250 & & Feb. 1 & 250 & $X$ \\
\hline 14 & & $x$ & 2 & & $x$ \\
\hline 17 & 500 & $X$ & 4 & 250 & $\mathrm{X}$ \\
\hline 18 & 500 & & 5 & 250 & \\
\hline 19 & 250 & $x$ & 6 & 250 & $x$ \\
\hline Subtotal & 10491 & 21 & Subtotal & 9150 & 20 \\
\hline
\end{tabular}


WATER ADDED TO TANK 105-A

FROM 11/1/73 THROUGH 12/31/74 (Cont.)

\section{DATE GALLONS CIRCULATORS SPRINKLED FLUSHED \\ LUSHED}

Feb. 7250

$8 \quad 250$

$11 \quad 250$

$12 \quad 250$

$13 \quad 250$

$14 \quad 250$

$15 \quad 250$

$18 \quad 250$

$19 \quad 250$

$20 \quad 250$

$21 \quad 250$

22

$25 \quad 250$

$26 \quad 250$

$28 \quad 250$

Mar. 1250

3

4250

$5 \quad 250$

6250

$8 \quad 250$

$11 \quad 250$

$12 \quad 250$

$13 \quad 250$

$14 \quad 360$

$18 \quad 300$

$19 \quad 250$

$20 \quad 250$

$21 \quad 250$

$22 \quad 350$

23

25

26

27

28

29

30

31

Apr. 1

2

Apr. 3

4

5

Subtotal
$\mathrm{X}$

$\mathrm{X}$

$\mathrm{x}$

$\mathrm{x}$

$\mathrm{x}$

$\mathrm{X}$

$\mathrm{X}$

$\mathrm{x}$

$\mathrm{X}$
$\mathrm{X}$
$\mathrm{X}$

250

250

250

250

250

350

250

250

250

250

9860

$\mathrm{X}$

$\mathrm{X}$

$\mathrm{X}$

\section{DATE}

Apr. 6$$
7
$$

8

9
10

10

15

15

17

19

22

23

24

26

29

30

May 1

2
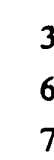

7

$$
9
$$

$$
10
$$$$
11
$$$$
13
$$

$$
14
$$$$
15
$$$$
15
$$$$
17
$$$$
18
$$$$
19
$$$$
20
$$$$
21
$$$$
22
$$

Jun. 1

2

3

Subtotal
GALLONS

SPRINKLED

CIRCULATORS

FLUSHED

$\begin{array}{ll}150 & \\ 250 & X \\ 250 & X \\ 250 & X \\ 250 & X \\ & X \\ 250 & X\end{array}$

400

250

250

500

250

250

500

250

250

250

250

250

250

250

250

250

250

250

250

250

250

250

500

250

250

250

250

240
$\mathrm{X}$

$\mathrm{x}$

$\mathrm{X}$

$\mathrm{X}$

X

$x$

$\mathrm{X}$

$\mathrm{x}$

$\mathrm{X}$

$\mathrm{x}$

$\mathrm{X}$

$\mathrm{X}$

$\mathrm{x}$

$\mathrm{x}$

$\mathrm{X}$

$\mathrm{x}$

$\mathrm{X}$

$\mathrm{X}$

$\mathrm{x}$

$\mathrm{X}$

$\mathrm{x}$

$x$

X

$x$

$x$

X

$\mathrm{X}$

$\mathrm{X}$

$\mathrm{X}$

$\mathrm{X}$

$\mathrm{x}$

$\mathrm{X}$

30 
WATER ADDED TO TANK 105-A

FROM 11/1/73 THROUGH 12/31/74 (Cont.)

\begin{tabular}{|c|c|c|c|c|c|}
\hline DATE & $\begin{array}{c}\text { GALLONS } \\
\text { SPRINKIED }\end{array}$ & $\begin{array}{l}\text { CIRCULATORS } \\
\text { FLUSHED }\end{array}$ & DATE & $\begin{array}{l}\text { GALLONS } \\
\text { SPRINKLED }\end{array}$ & $\begin{array}{l}\text { CIRCULATORS } \\
\text { FLUSHED }\end{array}$ \\
\hline June 4 & 250 & & Aug. 14 & 500 & $X$ \\
\hline 5 & 250 & $X$ & 16 & 250 & $x$ \\
\hline 6 & 250 & & 19 & 250 & $x$ \\
\hline 7 & 250 & $X$ & 21 & 250 & $X$ \\
\hline 10 & 250 & $X$ & 22 & 240 & \\
\hline 11 & 250 & & 23 & 240 & $X$ \\
\hline 12 & 250 & $X$ & 26 & 500 & $X$ \\
\hline 13 & 250 & & 27 & 240 & \\
\hline 14 & 250 & $x$ & 28 & 240 & $X$ \\
\hline 17 & 250 & $x$ & 30 & 500 & $X$ \\
\hline 19 & & $\mathrm{X}$ & Sept. 2 & 500 & \\
\hline 20 & 250 & & 4 & 240 & $X$ \\
\hline 21 & & $x$ & 5 & 240 & \\
\hline 23 & 241 & & 6 & Say 240 & $x$ \\
\hline 24 & 500 & $X$ & 9 & 480 & $X$ \\
\hline 28 & 250 & $\mathrm{X}$ & 10 & 480 & \\
\hline July 2 & & $X$ & 11 & 500 & $x$ \\
\hline 3 & & $x$ & 13 & 250 & $x$ \\
\hline 5 & & $X$ & 16 & 250 & $x$ \\
\hline 9 & 550 & $X$ & 17 & 500 & \\
\hline 10 & 500 & & 18 & & $x$ \\
\hline 11 & 250 & & 19 & 240 & \\
\hline 12 & 250 & $x$ & 20 & 500 & $\mathrm{x}$ \\
\hline 15 & 250 & $X$ & 24 & 250 & \\
\hline 16 & 250 & & 25 & & $X$ \\
\hline 17 & 250 & $X$ & 26 & 250 & \\
\hline 18 & 250 & & 27 & 250 & $X$ \\
\hline 19 & 250 & $X$ & 30 & 500 & $x$ \\
\hline 22 & 250 & & Oct. 1 & 240 & \\
\hline 23 & 250 & & 2 & 1500 & $x$ \\
\hline 24 & 250 & $X$ & 3 & & $x$ \\
\hline 25 & 500 & & 4 & & $x$ \\
\hline 26 & & $x$ & 7 & & $x$ \\
\hline 29 & 500 & $x$ & 8 & 240 & $x$ \\
\hline 30 & 250 & & 9 & 1500 & \\
\hline 31 & 250 & $X$ & 11 & & $X$ \\
\hline Aug. 1 & 500 & & 14 & & $x$ \\
\hline 2 & & $X$ & 16 & 250 & $\mathrm{X}$ \\
\hline 5 & & $x$ & 18 & 240 & $\mathrm{X}$ \\
\hline 7 & 250 & $X$ & 21 & 250 & $\mathrm{X}$ \\
\hline 9 & & $x$ & 22 & 240 & \\
\hline 12 & 500 & $X$ & 23 & 500 & $x$ \\
\hline 13 & 250 & & 25 & 240 & $x$ \\
\hline Subtotal & 10291 & 27 & Subtotal & 14080 & 31 \\
\hline
\end{tabular}


FROM 11/1/73 THROUGH 12/31/74 (Cont.)

\section{DATE \\ GALLONS
SPRINKLED}

Oct. 28

29

240

240

240

240

Nov. 1

$4 \quad 240$

$5 \quad 350$

6

8240

$11 \quad 240$

$12 \quad 240$

$13 \quad 240$

$14 \quad 240$

$15 \quad 260$

$18 \quad 240$

$19 \quad 500$

20

21

22

23

24

25

27

28

Subtotal

240

Say 240

4230

\section{CIRCULATORS \\ FLUSHED}

$\mathrm{X}$

$\mathrm{X}$

$\mathrm{X}$

$\mathrm{X}$

$\mathrm{X}$

$\mathrm{X}$

$\mathrm{X}$

$\mathrm{X}$

$\mathrm{X}$

$\mathrm{X}$

DATE

$\mathrm{x}$

$\mathrm{x}$

$\mathrm{x}$

$x$

$x$

$\mathrm{X}$

$\mathrm{X}$

$\mathrm{x}$

$\mathrm{X}$

$\mathrm{x}$

$\mathrm{X}$

15

Dec. 2

$$
3
$$

4

6

11

12

13

15

16

17

18

19

20

22

23

25

26

27

30

31

15
GALLONS SPRINKIED

$9 \quad 240$

CIRCULATORS

FLUSHED

$\mathrm{X}$

240

$x$

$\mathrm{X}$

$\mathrm{x}$

$\mathrm{x}$

$\mathrm{x}$

$\mathrm{X}$

$\mathrm{X}$

$\mathrm{x}$

X

240

240

240

720

$x$

$\mathrm{X}$

12

$x$
$x$
$x$
$x$
$x$
$x$
$x$
$x$
$x$
$x$
$x$

$$
\begin{array}{ll}
\text { Average rate for the time period } & =\frac{72482+(180)(171)}{(61+365)} \\
& =242 \mathrm{gal} / \mathrm{day} \\
& =\frac{(242)(8.35)(1000)}{(24)} \\
& =84,200 \mathrm{Btu} / \mathrm{hr}
\end{array}
$$


WATER ADDED TO TANK 105A

FROM 1/1/75 THROUGH 12/31/75

Source: $\quad$ Status Report 241-A Tank Farm (Archives Box No. 58071)

\begin{tabular}{|c|c|c|c|c|c|}
\hline DATE & $\begin{array}{l}\text { GALLONS } \\
\text { SPRINKLED }\end{array}$ & $\begin{array}{l}\text { CIRCULATORS } \\
\text { FLUSHED }\end{array}$ & DATE & $\begin{array}{l}\text { GALLONS } \\
\text { SPRINKIED }\end{array}$ & $\begin{array}{l}\text { CIRCULATORS } \\
\text { FLUSHED }\end{array}$ \\
\hline Jan. 1 & 240 & & Feb. 25 & 240 & \\
\hline 3 & & $\mathrm{X}$ & 26 & & $\mathrm{X}$ \\
\hline 4 & Say 250 & & 27 & 480 & \\
\hline 6 & 480 & $X$ & 28 & & $\mathrm{X}$ \\
\hline 8 & & $\mathrm{X}$ & Mar. 3 & 525 & $X$ \\
\hline 9 & 480 & & 4 & 250 & \\
\hline 10 & & $\mathbf{X}$ & 5 & & $\mathrm{X}$ \\
\hline 13 & 670 & $\mathbf{X}$ & 6 & 1030 & \\
\hline 15 & 250 & $\mathrm{X}$ & 7 & & $X$ \\
\hline 16 & 240 & & 10 & & $\mathrm{X}$ \\
\hline 17 & 240 & $\mathrm{x}$ & 12 & 644 & $\mathrm{X}$ \\
\hline 18 & & $\mathrm{x}$ & 14 & 565 & $\mathrm{x}$ \\
\hline 20 & 480 & $\mathrm{x}$ & 17 & & $\mathrm{x}$ \\
\hline 21 & 240 & & 18 & 756 & \\
\hline 22 & & $x$ & 19 & & $X$ \\
\hline 23 & 240 & & 21 & 941 & $x$ \\
\hline 24 & 240 & $\mathrm{x}$ & 24 & & $\mathrm{X}$ \\
\hline 27 & 480 & $\mathrm{X}$ & 25 & 500 & \\
\hline 28 & 240 & & 26 & & $\mathrm{x}$ \\
\hline 29 & & $\mathrm{x}$ & 28 & 880 & $\mathrm{X}$ \\
\hline 30 & 480 & & 31 & 250 & $\mathrm{X}$ \\
\hline 31 & & $\mathrm{X}$ & Apr. 1 & 240 & \\
\hline Feb. 3 & 480 & $\mathbf{X}$ & 2 & 240 & $x$ \\
\hline 4 & 240 & & 3 & 240 & \\
\hline 5 & & $\mathrm{X}$ & 4 & 240 & $X$ \\
\hline 6 & 480 & & 7 & 500 & $\mathrm{x}$ \\
\hline 7 & Say 1750 & $\mathrm{x}$ & 8 & 750 & \\
\hline 10 & & $x$ & 9 & & $\mathrm{X}$ \\
\hline 12 & & $\mathrm{X}$ & 11 & 500 & $x$ \\
\hline 14 & & $\mathrm{x}$ & 14 & 500 & $\mathrm{X}$ \\
\hline 18 & 240 & & 16 & 400 & $x$ \\
\hline 19 & 240 & $x$ & 18 & & $x$ \\
\hline 20 & 240 & & 21 & 500 & $\mathrm{x}$ \\
\hline 21 & 480 & $\mathrm{X}$ & 22 & 500 & \\
\hline 24 & 240 & $\mathrm{X}$ & 23 & & $\mathrm{x}$ \\
\hline Subtotal & 9640 & 23 & Subtotal & 11671 & 25 \\
\hline
\end{tabular}


WATER ADDED TO TANK 105A

FROM 1/1/75 THROUGH 12/31/75 (Cont.)

\section{DATE GALLONS CIRCULATORS SPRINKLED FLUSHED

SHED

Apr. 24

25

$28 \quad 700$

$30 \quad 300$

May 2600

$5 \quad 500$

7

9

12

14

15

16

19

20

21

23

28

30

June 2

4

9

10

11

12

13

16

18

20

23

25

30

Jul. 2

7

9

13

14

16

18

21

22

23

24

Subtotai
500

500

500

500

500

500

589

710

536

550

500

500

500

500

$\mathrm{X}$

$\mathrm{X}$

$\mathrm{X}$

$\mathrm{X}$

$50 C$

500

500

500

500

250

250

525

13010

$\mathrm{X}$

$\mathrm{X}$

$\mathrm{X}$

$\mathrm{X}$

$\mathrm{X}$

$\mathrm{X}$

$\mathrm{X}$

$\mathrm{X}$

$\mathrm{X}$

$\mathrm{x}$

$\mathrm{X}$

$\mathrm{X}$

$\mathrm{x}$

$x$

$\mathrm{X}$

$\mathrm{X}$

$\mathrm{X}$

$\mathrm{x}$

$\mathrm{X}$

$\mathrm{X}$

$\mathrm{X}$

$\mathrm{X}$

$\mathrm{X}$

$\mathrm{x}$

$\mathrm{X}$

$\mathrm{X}$

$\mathrm{X}$

$\mathrm{X}$

$\mathrm{X}$

$\mathrm{X}$

34
DATE

Jul. 28

30

Aug. 1

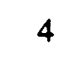

6

8

25

26

27

28

Sept. 8

12

15

17

19

22

24

29

Oct. 1
GALLONS SPRINKLED

\begin{abstract}
600
\end{abstract}
450

6000

CIRCULATORS

FLUSHED

$\mathrm{X}$

$\mathrm{X}$

$\mathrm{X}$

$\mathrm{X}$

$\mathrm{X}$

$\mathrm{X}$

$\mathrm{x}$

$\mathrm{X}$

$\mathrm{x}$

$\mathrm{x}$

565

700

500

500

357

782

500

600

600

300

500

800

700

800

800

500

800

500

500

500

Nov. $4 \quad 500$

7690

$10 \quad 380$

$11 \quad 150$

$13 \quad 350$

$16 \quad 250$

$17 \quad 750$

$20 \quad 900$

$24 \quad 550$

$25 \quad 500$

Dec. 2700

$5 \quad 700$

$9 \quad 707$

Subtotal 29781 
WATER ADDED TO TANK 105A

FROM 1/1/75 THROUGH 12/31/75 (Cont.)

$\begin{array}{ccc}\text { DATE } & \text { GALLONS } & \text { CIRCULATORS } \\ \text { SPRINKIED } & \text { FLUSHED }\end{array}$

Dec. 11700

$15 \quad 700$

$18 \quad 750$

$23 \quad 650$

$26 \quad 350$

$29 \quad 650$

Subtotal $\quad 3800$

0

Average rate for 1975

$=\frac{64102+(180)(92)}{365}$

$=221 \mathrm{gal} / \mathrm{day}$

Heat required to evaporate

$=\frac{(221)(8.35)(1000)}{(24)}$

(24)

$=76,900 \mathrm{Btu} / \mathrm{hr}$ 
WATER ADDED TO TANK 105-A

FOM 1/1/76 THROUGH 12/31/76

Source: $\quad$ Status Report-241A - Tank Farm and

Tank Farm Liquid Level Readings (Archives Box No. 58073)

\section{DATE GALLONS SPRINKIED}

Jan. 21000

$7 \quad 600$

9500

13550

$16 \quad 750$

$19 \quad 600$

23800

$27 \quad 600$

$30 \quad 650$

Feb. $4 \quad 625$

6725

13900

$20 \quad 500$

$23 \quad 535$

$27 \quad 500$

Mar. $1 \quad 800$

$5 \quad 500$

$12 \quad 500$

$15 \quad 600$

$22 \quad 750$

$26 \quad 700$

$29 \quad 800$

Apr. $2 \quad 800$

7800

$9 \quad 415$

$14 \quad 240$

$16 \quad 244$

$28 \quad 240$

May 4 Say 500

250

250

253

250

250

250

19177

\section{DATE \\ GALLONS SPRINKLED}

May 15

17

17

18

21

22

23

24

25

27

28

31

Jun. 2

3

4

7

8

8

9

10

11

14

15

17

18

21

22

23

24

25

28

29

30

Jul. 1

2

7

8

Subtotal

240

240

240

241

266

251

244

240

240

240

240

240

240

240

240

240

240

240

240

240

240

240

240

240

240

240

240

240

240

1000

240

240

240

240

240

9202

\section{DATE GALLONS SPRINKLED}

Jul. 9240

$12 \quad 240$

$13 \quad 1000$

$14 \quad 240$

$15 \quad 240$

$16 \quad 240$

$17 \quad 240$

$19 \quad 240$

$20 \quad 240$

$21 \quad 240$

$22 \quad 240$

$23 \quad 240$

$25 \quad 240$

$26 \quad 240$

$27 \quad 249$

$28 \quad 240$

$29 \quad 240$

$30 \quad 240$

Aug. 12240

$2 \quad 250$

3240

$4 \quad 240$

$5 \quad 400$

$6 \quad 240$

11550

$12 \quad 510$

$30 \quad 800$

Sep. $2 \quad 850$

$6 \quad 300$

$7 \quad 800$

$10 \quad 500$

$14 \quad 2000$

$29 \quad 736$

Oct. $6 \quad 100$

$11 \quad 500$

Subtotal

14295 
WATER ADDED TO TANK 105A

FROM 1/1/76 THROUGH 12/31/76 (Cont.)

\section{DATE GALLONS SPRINKIED}

Oct. 12

500

13550

$15 \quad 500$

$19 \quad 500$

$22 \quad 500$

$24 \quad 500$

$27 \quad 1000$

Nov. $1 \quad 1350$

21000

$14 \quad 250$

$16 \quad 500$

$18 \quad 500$

$20 \quad 500$

25

Subtotal

\section{DATE}

Nov. 28

29 Say 250

Dec. 3

$$
7
$$

500

9

10

13

14

15

23

24

27

29

3

Subtotal
GALLONS SPRINKLED

500

500

500

500

500

500

500

500

500

500

400

850

250

6750

$$
\begin{array}{ll}
\text { Average rate for } 1976 & =\frac{58024}{366} \\
& =159 \mathrm{gal} / \text { day }
\end{array}
$$

Heat required to evaporate $=\underline{(159)(8.35)(1000)}$

(24)

$=55,300 \mathrm{Btu} / \mathrm{hr}$. 
Source: Status Report - 241A Tank Farm and

Tank Farm Liquid Level Readings (Archives Box No. 61285)

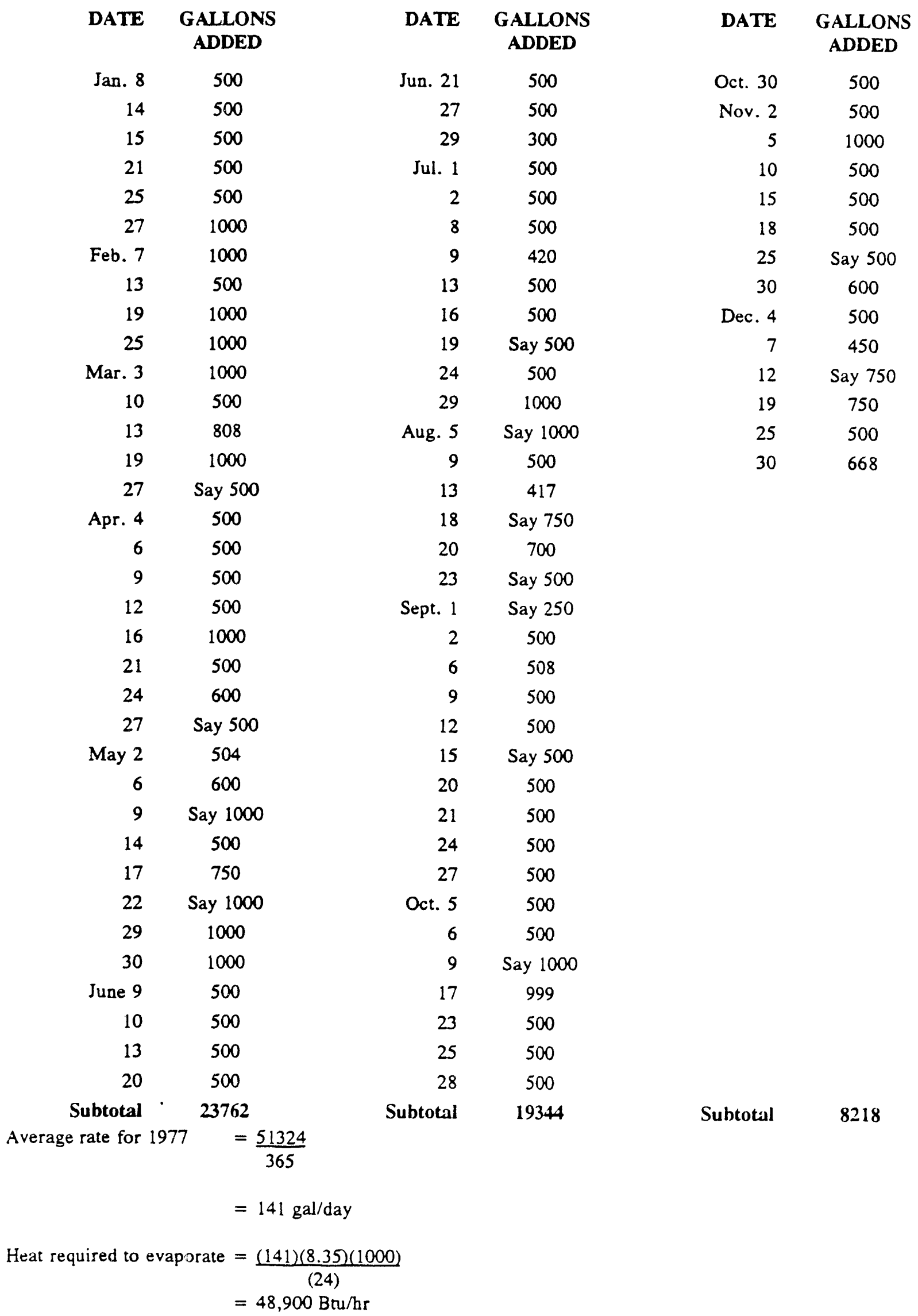


WATER ADDED TO TANK 105-A

FROM $1 / 1 / 78$ TO $12 / 4 / 78$

Source: Status Report - 241A Tank Farm, and

Tank Farm Liquid Level Readings (Archives Box No.68653)

\section{DATE \\ GALLONS SPRINKLED}$$
\text { Jan. } 3
$$

500

$5 \quad$ Say 500

13500

$17 \quad 500$

$22 \quad 500$

$26 \quad 500$

$31 \quad 500$

Feb. $6 \quad 1000$

$7 \quad 500$

$18 \quad 500$

$20 \quad 500$

$26 \quad 625$

Mar. $4 \quad 500$

6946

9910

24 Say 500

$26 \quad 400$

$29 \quad 400$

$31 \quad 998$

Apr. 6 Say 500

$10 \quad 500$

115500

$18 \quad 500$

$22 \quad 1000$

$29 \quad 952$

May $4 \quad 500$

$7 \quad 500$

11500

$27 \quad 516$

June $2 \quad 500$

$7 \quad 500$

$11 \quad 500$

16 Say 1500

$20 \quad 500$

$27 \quad 437$

Jul. 2 Say 1500

$5 \quad 500$

9500

15 Say 500

Subtotal 24184

\section{DATE GALLONS \\ SPRINKLED}

$\begin{array}{rr}\text { Jul. } 18 & 500 \\ 26 & 585 \\ 28 & 500\end{array}$

Aug. $1 \quad 593$

6500

$12 \quad 805$

$16 \quad 516$

$23 \quad 500$

$24 \quad 500$

$25 \quad 113$

$26 \quad 502$

$30 \quad 300$

Sept. $3 \quad 602$

7 Say 500

11495

$13 \quad 474$

$19 \quad 513$

$21 \quad 741$

$22 \quad 400$

$30 \quad 500$

Oct. $8 \quad 503$

$10 \quad 516$

$16 \quad 500$

$21 \quad 500$

$25 \quad 481$

$31 \quad 500$

Nov. $3 \quad 516$

$\begin{array}{ll}7 & 537\end{array}$

$16 \quad 600$

$21 \quad 500$

$25 \quad 538$

$29 \quad 559$

Dec. $4 \quad 410$

Subtotal $\quad 16799$ 
WATER ADDED TO TANK 105-A

FROM 1/1/78 TO 12/4/78 (Con't.)

$$
\begin{aligned}
\text { Average rate for the time period } & =\frac{40983}{338} \\
& =121 \mathrm{gal} / \mathrm{day} \\
& =\frac{(121)(8.35)(1000)}{(24)} \\
\text { Heat required to evaporate } & =42,100 \mathrm{Bru} / \mathrm{hr}
\end{aligned}
$$


8.3 Bibliography 
* will be released in a MISC. REPORT (WHC-MR-0250)

** will be individually released

(note: listed by author or requestor)

Aichele, W.T., PSYCHROMETRIC SURVEY TANK 105-A, RI, 11/12/82, Richland, Washington

Aichele, W.T., TEMPERATURE SURVEY AT 105 \&. TANK, RI, 12/06/82, Richland, Washington

Aichele, W.T., TANK TEMPERATURE SURVEY, RI, 11/18/82, Richland, Washington

Alstad, A.T.; DSI to R.T. Kimura; "P-17 EXHAUSTER IN A FARM"; 13 March 1990.

Anderson, B.N. and C.M. Walker.RHO-CD-213, WASTE STORAGE TANK STATUS AND LEAK DETECTION CRITERIA,

Anderson, B.W., MONTHLY BOLLOFF RATES - JUNE 1965 TO MARCH 1972,ARHC internal letter.

Anderson, J.D., A HISTORY OF THE 200 AREA TANK FARMS WHC-MR-0132, June, 1990.

*Anderson, S.I. NUCLEAR SAFETY COMMENTS FOR THE KYSHTYM EXPLOSION AND EXPLOSION HAZARDS WITH NITRATE-NITRITE BEARING WASTES AND ACETATES OR ACETATE-LIKE ORGANIC SUBSTANCES (DRAFT 3/12/90), 90-054-SIA, Westinghouse Hanford Company, Richland, Washington

*Anonymous, MEETING NOTES RE: 105-A SLUICING, 9/29/77.

*Anonymous, SLUDGE, no date.

*Bailey, J.W. to J.L. Deichman, NOTES ON SURVEILLANCE RELATED OUESTIONS, 10/9/79

Barnes, R.G. and Hanson, G.L., 1958, "INTERIM REPORT ON DISPLACEMENT OF THE REDOX 113-SX WASTE STORAGE TANK LINER"; HW-57249

Baumhardt, R.J., Manager, Tank Farms, Defense Waste Management Division; "SINGLE-SHELL TANK LEAK VOLUMES"; To R.E. Gerton; 17 May 1989; WHC Letter \# 8901832B R1, attachment. 
Beard, S.J., Hatch, P., and Watson, E.C. Jr., 1967, "PUREX TK-105-A WASTE STORAGE TANK LINER INSTABILITY AND ITS IMPLICATION ON WASTE CONTAINMENT AND CONTROL"; ARH-78.

Beard, S.J. and B.F. Judson,RL-SEP-87, PUREX WASTE TANK 241-A-105 FILL LIMIT, 11/17/64.

Bracken, Gary J., Acting Director, Waste Management Division, DOE-RL; "SINGLESHELL TANK LEAK VOLUMES"; To WHC; 27 April 1989; DOE-RL Letter \#8901832B.

Britton, M.D., 1990, "105-A HEAT BALANCE - EVAPORATION"; EDT \#125702.

Britton, M.D., 1990, "A-105 HISTORICAL LATERAL TEMPERATURES GRAPH"; TRAC 0037.

Britton, M.D., 1990, "A-105 IN-TANK PHOTOGRAPHS"; TRAC 0038.

Britton, M.D., 1990, "A-105 SLUDGE TEMPERATURES, JANUARY '89 TO NOVEMBER '90"; TRAC 0039.

Britton, M.D., 1990, "A-105 LATERAL TEMPERATURES, JANUARY '89 TO NOVEMBER' '90"; TRAC 0040.

Britton, M.D., 1990, "STATUS REPORT - 241-A TANK FARM: 10-31-71"; TRAC 0054.

Britton, M.D., 1990, "STATUS REPORT - 241-A TANK FARM: 11-1-73 TO 12-3173"; TRAC 0058.

Britton, M.D., 1990, "STATUS REPORT - 241-A TANK FARM: 1-1-74 TO 12-31-74"; TRAC 0059.

Britton, M.D., 1990, "STATUS REPORT - 241-A TANK FARM: 1-1-75 TO 3-31-75"; TRAC 0060.

Britton, M.D., 1990, "STATUS REPORT - 241-A TANK FARM: 10-2-75 TO 12-3175"; TRAC 0061.

Britton, M.D., 1990, "STATUS REPORT - 241-A TANK FARM: 1-2-76 TO 4-30-76"; TRAC 0062.

Britton, M.D., 1990, "STATUS REPORT - 241-A TANK FARM: 1-1-77 TO 12-31-77"; TRAC 0063. 
Britton, M.D., 1990, "STATUS REPORT - 241-A TANK FARM: 1-1-78 TO 12-31-78"; TRAC 0064.

Britton, M.D., 1990, "STATUS REPORT - 241-A TANK FARM: 1-1-79 TO 12-31-79"; TRAC 0065.

Britton, M.D., 1990, "STATUS REPORT - 241-A TANK FARM: 8-3-81 TO 7-25-83"; TRAC 0066.

Brownell, L.E., 1958, "INSTABILITY OF STEEL BOTTOMS IN WASTE STORAGE TANKS"; HW-57274.

Buckingham, J.S., and M.J. Kupfer; "PROPOSED LABORATORY WORK FOR CHEMICAL MILLING OF TANK 105-A BULGE"; To J.D. Kaser; October 6, 1977; Rockwell International Letter.

Buckingham, J.S., KF53E - WASTE CONCENTRATION, WASTE CONCENTRATION PROCESS TECHNOLOGY, KF53E, RI, 2/3/78, Richland, Washington

Butler, R.L., MOVE PORTABLE EXHAUSTER FROM 103-AX TO 105-A, RI, 6/22/78, Richland, Washington

Cain, R.J., TF Process Engineering; "FEASIBILITY STUDY - WATER ADDITION TO TANK 105-A"; To J.C. Womack; 20 October 1977; Rockwell International Letter, 5 attachments.

Campbell, G.D., RHO-LD-171, HEAT TRANSFER ANALYSIS FOR IN SITU DISPOSAL OF NUCLEAR WASTES IN SINGLE- AND DOUBLE-SHELL UNDERGROUND STORAGE TANKS", dated October 1981.

*Campbell, E. J., to R.E. Raymond, RESPONSE TO QUERY, TANK 105-A, 10/29/90.

Carl, B.P., 1978, "ELIMINATION OF WATER ADDITION TO TANK 105-A TANK FARM PROCESS TEST PLAN 781 (PART 1)"; RHO-CD-625.

Carl, B.P.; "TESTING OF CHEMICAL MILLER"; To T.B. Veneziano; September 25, 1978; Rockwell International letter No. 60412-78-0403 .

Carl, B.P.; "AMOUNT OF N, SUFFICIENT TO RUN ACID MLLER"; To T.B. Veneziano; September 20, 1978; Rockwell International Letter \# 60412-78-0396.

*Carl, B.P.; INTERIM STABILIZATION EVALUATION, 7/31/79. 
*Carl, B.P.; "IN TANK SPRINKLING", 10/17/78.

Carlson, C.E., DE-ENTRAINER DESIGN FOR THE 241-A-105 PORTABLE

EXHAUSTER, RI, 10/21/82, Richland, Washington

Catlin, R. J., "ASSESSMENT OF THE SURVEILLANCE PROGRAM OF THE HIGHLEVEL WASTE STORAGE TANKS AT HANFORD", dated March 1980.

Dahlberg, P.R., REPLACEMENT AND HOOK-UP OF MOBLLE EXHAUSTER UNIT TO TANK RISER 105 AT 241-A, RI, 2/15/78, Richland, Washington

Doud, E. and H.W. Stivers,HW-59919, LIMITATIONS FOR EXISTING STORAGE TANKS FOR RADIOACTIVE WASTES FROM SEPARATIONS PLANTS, 10/22/59.

Dukelow, G.T.; "LIQUID LEVEL TAPE INSTALLATION"; To Tank Farm Operations Supervision; 6 December 1976; Atlantic Richfield Hanford Co. Letter.

*Dukelow, G.T. TANKS WHICH PRESENT A POTENTIAL FOR REDUCED STRUCTURAL INTEGRITY, 65260-79-0730, RI, Richland, Washington

*Dunford, G.L., SUMMARY OF LEAKER OR OUESTIONABLE INTEGRITY TANKS, 8/19/88.

Elgert, O.J.; "SAFETY ANALYSIS FOR TANK 105-A"; To General Manager, Rockwell Hanford Operations; June 26, 1978; DOE Letter \# 11305; 000783.

*Elgert, O.J., to General Manager Rockwell Hanford Operations, STABILIZATION OF WASTE TANK 241-A-105, 7/27/77.

Everly, D.W., and S.S. Bath, Waste Processing Technology; "HEAT TRANSFER STUDY ON TANK 105-A"; To T.B. Veneziano; 10 August 1978; Rockwell International Letter \# 60414-78-051, 5 attachments.

Everly, D.W.; "TRANSIENT HEAT TRANSFER STUDY ON TANK 105-A"; To T.B. Veneziano; November 21, 1978; Rockwell International Letter \# 60413-78-0132.

**Fecht, J.B., HAZARDS REVIEW - SALT CAKE STORAGE FACILITIES AT 241-A AND 241-AX TANK FARMS (PROJECT B-102), ARH-CD-514, Atlantic Richfield Company, 12/03/75, Richland, Washington

Felt, R. E., A AND AX TANK SLUDGE HEAT GENERATION RATES, RI, Richland, Washington 
Fisher, T.W., "THERMAL ANALYSIS OF SST-A-105"; WHC-SD-WM-DA-061, Rev. 0 .

Fisher, T.W., Chen, W.W. and Pan, R.B., 1990, "THERMAL AND STRUCTURAL ANALYSIS OF SINGLE-SHELL TANK A-105"; WHC-SD-WM-DA-064 Rev 0.

Fordham, C.R. (Chuck); "TEST PROCEDURE FOR 105-A TANK LATERAL THERMOCOUPLES"; To Richard C. Garrison; November 1, 1990; WHC ce Mail.

Francis, C.J. and Oberg, G.C., 1970, "REVISED SPECIFICATIONS AND STANDARDS TO PERMIT SLUDGE REMOVAL FROM TK-241-A-105"; ARH-1814.

*Fraser, M.C. and D.J. Larkin; "RADIONUCLIDE INVENTORIES IN LEAKS FROM TRANSFER LINES AND TANKS"; To H.P. Shaw; 30 January 1974; Atlantic Richfield Hanford Co. Letter.

*Geier, R. G., WASTE TANK DOME ELEVATIONS, Atlantic Richfield Company, 8/10/76, Richland, Washington

Gibby, R.D. to V.D. Maupin,WHC Internal Memo 13316-89-042, HIGH HEAT SINGLE-SHELL TANKS, April 20, 1989.

Godfrey, W.L. and W.C. Schmidt,RHO-R-39, BOILING WASTE TANK FARM OPERATIONAL HISTORY, 12/18/69.

Grelecki, Chester, Ph.D., Hazards Research Corp.; "NO SUBJECT"; To C.M. Walker, Atlantic Richfield Hanford Company; 21 December 1976.

Groves, S., SPECIAL SURVEY OF A FARM 105-A AREA, E8402055, RI, 8/16/84, Richland, Washington

Groves, S., SPECIAL SURVEY OF A FARM 105-A AREA, E8402108, RI, 8/30/84, Richland, Washington

*Hamilton, W.H.,Jr.,WHC memo, OCTOBER 5 TANK 105-A MEETING, 10/8/90.

**Hamilton, W.H., SINGLE-SHELL TANK LEAK VOLUMES, 9004655B R1, Westinghouse Hanford Company, 11/5/90, Richland, Washington

Hamilton, W.H. letter, Attachment 1A

Hanlon, B.M.; "105-A SLUDGE TEMPERATURES"; DSI to R.T. Kimura; November 30, 1989 . 
Hanson, G.L., Stivers, H.W. and Stong, F.S.,1962, "LEAK TESTING OF THE 113-SX TANK"; HW-75714.

*Harlow, D.G. et al. to Zinsli, R.A., TANK 105-A CHEMICAL MLLING TASKS READINESS REVIEW, Rockwell International, 9/19/78 Richland, Washington

Hatch, P.; "INSPECTION OF CONCRETE CORE SAMPLES TAKEN FROM DOME OF 105-A TANK"; To G.C. Oberg; March 8, 1966; SST RECORD \# T00409.

*Hatch, P. "Trip Report Covering Scale Model Testing of Waste Tank Dome", to H.L. Caudill, January 14, 1969

Hatch, P. , ARH-951, LIMITATIONS FOR USE OF UNDERGROUND WASTE TANKS, 12/18/69.

**Isaacson, R.E. and Gasper, K.A., RHO-ST-34, A SCIENTIFIC BASIS FOR ESTABLISHING DRY-WELL MONITORING FREQUENCIES, December 1981.

*Jacobs, M.C. to R.E. Roberts,ARHC memo, WASTE MANAGEMENT STARTUP DATES, 7/13/70.

Jansen, G. Jr., et al. BNWL-CC-376, TECHNIQUES FOR CALCULATING TANK TEMPERATURES AND SOIL TEMPERATURES NEAR LEAKS - APPLICATION TO PUREX WASTE TANK 105A, December 22, 1965.

Jungfleisch, F.M., SD-WM-TI-057, "PRELIMINARY ESTIMATION OF THE WASTE INVENTORIES IN HANFORD TANKS THROUGH 1980", dated 1980.

Kaser, J.D.; "DISCUSSION OF TANK 105-A WITH CONSULTANTS"; September 23, 1977; Rockwell International Letter 0133.

Kaser, J.D.; "TANK 105-A CONSULTANT MEETING, NOVEMBER 3, 9:00 A.M., 2570-E CONF. ROOM"; October 28, 1977; Rockwell International Letter 0181.

*Kaser, J., TANK 105-A AND A.I.INVOLVEMENT, 10/7/77.

Kaser, J.D. and Veneziano, T.B., 1978, "TANK 105-A STABLIZATION PROGRESS REPORT"; RHO-CD-255.

Kilgore, Ed; "NO SUBJECT"; To John Cashman; February 23, 1978; Hand written letter.

Kimura, R.T.; DSI to Don Wodrich; "105-A LATERAL TEMPERATURE; 1965PRESENT"; 22 November 1989. 
Kimura, R.T.; DSI to A.T. Alstad; "105-A EXHAUSTER"; 3 January 1990.

Kimura, R.T.; DSI to T.D. Blankenship; "105-A EXHAUSTER 'OSD VIOLATION'"; 12 March 1990.

Kimura, R.T.; DSI to A.T. Alstad; "SST-A-105 THERMAL ANALYSIS"; 27 April 1990.

Kimura, R.T., 105-A ALTERNATE VENTLLATION, Westinghouse Hanford Company, 10/30/90, Richland, Washington

Kimura R.T.; DSI to R.E. Raymond; "105-A LATERAL TEMPERATURES"; 14 May 1990.

Kirch, N.W.; "CONTAMINATION DUE TO TANK 241-A-105 INCIDENT"; To distibution; November 29, 1989; WHC Internal Memo 13314-89-120 T00318.

*Kirk, J.J.; DSI \#65413-79-163 to John Bailey; "LEAK RATES FROM TANKS CONTAINING NO SOLIDS"; 10 October 1979.

Koegler, S.S.; "A AND AX TANK SLUDGE HEAT GENERATION RATES", TO R.E. Felt, February 12, 1976.

Kupfer, M.J., KF53E - WASTE CONCENTRATION (KF53EE - TANK 105-A

CHEMICAL MILLING), KF53E, RI, 2/3/78, Richland, Washington

Kupfer, M.J., 1978, "STABILIZATION OF TANK 105-A LABORATORY PROGRAM"; RHO-CD-399.

Lane, T.A., and M.J. Kupfer; "LABORATORY STUDIES FOR TANK 105-A BULGE PENETRATION"; To J.D. Kaser; January 26, 1978; Rockwell Imternational Letter.

Lane, T.A.; "TANK 105-A CHEMICAL MIILLING"; To T.B. Veneziano; July 10, 1978; Rockwell International Letter \# 60120-78-060.

Lane, T.A.; "FURTHER INFORMATION FOR TANK 105-A CHEMICAL MILLING; To T.B. Veneziano; August 7, 1978; Rockwell International Letter \# 60120-78-060.

Lane, T.A.; "PROOF TEST OF TANK 105-A CHEMICAL MILLING HEAD"; To T.B. Veneziano; August 31, 1978; Rockwell International Letter \# 60120-78-090 J.

Lane, T.A., 1978, "LABORATORY SIMLLATION OF TANK 105-A CHEMICAL MILLING"; RHO-CD-443. 
Lane, T.A.; "ACID RESISTANCE OF CHEMICAL MILLING COMPONENTS"; To T.B. Veneziano; September 21, 1978; Rockwell International Letter \# 60120-78-098 J.

*Lewis, W.S. to S.J. Joncus, WHC Internal letter \#65950-86-437, "REPLACEMENT OF DEFECTIVE THERMOCOUPLES IN SINGLE-WALL TANKS", dated July 23, 1986.

Malody, C.W.; "ADDITION OF WATER TO TANK 105-A, CONTRACT E(45-1)2130"; To F.R. Standerfer; September 27, 1976; 000792.

Maupin, V.D.; "TANK STATUS CHANGE"; February 8, 1979; Rockwell International Letter \# 60411-79-0083.

*Maupin, V.D., PRIMARY STABILIZATION EVALUATION, 1/31/79.

**McCann, D.C. and Vail, T.S., RHO-RE-SR-14, WASTE STATUS SUMMARY SEPTEMBER 1984, 10/9/84

McMurray, B.J. et. al. , ISO-234, HAZARDS EVALUATION - EMERGENCY WASTE REMOVAL FACILITY 241-A-105, 4/20/66.

Merrick, D.L.; "ADDITION TO WEEKLY BRIEFING - WEEK ENDING AUGUST 9, 1978, WASTE PROCESSING 'TECHNOLOGY"; To D.G. Harlow; August 10, 1978;

Rockwell International Letter \# 60414-78-054; 000792.

Metz, W.P., 1978, "ACTION PLAN FOR STABLLIING TANK 241-A-105"; ARH-CD135.

**Muller, M.E., FUNCTIONAL DESIGN CRITERIA SALT CAKE STORAGE FACILITIES AT 241-A AND 241-AX TANK FARMS (PROJECT B-102), ARH-2952, $12 / 21 / 73$, Richland, Washington

Murthy, K.S. et al,PNL 4688, UC-70, ASSESSMENT OF SINGLE-SHELL TANK RESWUAL LIQUID ISSUES AT HANFORD SITE, WASHINGTON, June 1983.

Pan, R.B.; "SCHEDULE CHANGE TO THERMAL AND STRUCTURAL ANALYSIS OF SST A-105"; 30 May 1990; WHC Internal Memo \# 23480-90-72, attachment.

Pan, R.B.; "THERMAL AND STRUCTURAL ANALYSIS OF SINGLE-SHELL TANK A-105"; 11 June 1990; WHC Internal Memo $\$ 23480-90-83$, attachment.

Prosser, R.D.; "EMERGENCY PROCUREMENT OF TECHNICAL SERVICES FOR TANK 105-A"; To W.H. Dixon; September 15, 1977; Rockwell International Letter. 
Prosser, R.D.; "PURCHASE ORDER NUMBER W7G-SDB-24594"; To C.J. Grelecki, Hazards Restarch Corporation; September 20 1977; Rockwell International Letter 377298-R1.

Prosser, R.D.; "STABILIZATION OF TANK 105-A"; To H. Babad; September 16, 1977; Rockwell International Letter.

*Raymond, R.E., to R.C. Nichols, FACT SHEET ON TANK A-105 TEMPERATURES, 10/30/90.

Raymond, R.E.; DSI to S.I. Anderson; "RESPONSE TO SAFETY REVIEW COMMENTS ON PROPOSED TRANSMITTAL TO DOE-RL REGARDING SINGLESHELL TANK LEAKAGE TO SOHS"; 15 May 1989.

Raymond, R.E.; "SINGLE-SHELL TANK 241-A-105 LEAK VOLUME ESTIMATE"; To R.E. Gerton, DOE; October 26, 1990; WHC Letter \# 8901832B R2.

Raymond, R.E.; "TANK 241-A-105 THERMOCOUPLE ACCURACY"; To R.E. Gerton, DOE; November 7, 1990; WHC Letter 8901832B R3.

Raymond, R.E.; "105-A EXHAUSTER REPAIR"; 3 January 1990; WHC Internal Memo \# SST-90-0003, 2 attachments.

Reynolds, D.A.; "TEMPERATURE RISE IN LATERAL UNDER 241-1-105"; 3 January 1990; WHC Internal Memo \# 13314-89-132, 5 attachments; T00219.

*Raymond, R.E., RESPONSE TO SAFETY CONCERNS, SST-90-0101, Westinghouse Hanford Company, 10/29/90, Richland, Washington

Rice, P.D., PROCUREMENT SPECIFICATION FOR STAINLSS STEEL DE-ENTRANER FOR TANK 105-A, CK-2221-P1 RI, 9/30/82, Richland, Washington

**Roddy, L.W. and B.V. Snow,HW-83215, OPERATION OF A BOILING-WASTE TANK FARM, 7/8/64.

*Roecker, J.H., DECISION TO MEASURE HYDROGEN CONCENTRATION IN TANK 105-A BEFORE PERFORMING DRYING TESTS, 2/1/78, Rockwell Internal Letter 9606-R3.

Roecker, J. H., PROGRAM PLAN FOR STABILIZATION OF TANK 105-A, CONTRACT EY-77-C-06-1030, Atlantic Richfield Company, Richland, Washington 
Roecker, J.H.; "PROGRAM PLAN FOR STABLIZATION OF TANK 105-A CONTRACT EY-77-06-1030"; To O.J. Elgert; September 16, 1977; Rockwell International Letter \# 9606-R1, attachment.

Roecker, J.H.; "PROGRAM PLAN FOR STABILIZATION OF TANK 105-A CONTRACT EY-77-06-1030"; To O.J. Elgert; December 19, 1977; Rockwell International Letter \# 9606-R2, attachment.

Roecker, J.H., 1978, "RADIATION PEAK INCREASE IN 105-A LATERAL 14-05-03 EXCEEDING INCREASE CRITERIA"; Occurrence Report \#78-49 (INTERIM).

Routson, R.C. and J.B. Sisson; "RAW WATER LEAK IN 241-A TANK FARM ON FEBRUARY 23-24, 1978"; To E.H. Carbaugh; 13 March 1978; Rockwell International Letter.

Routson, R.C.; "CHANGING RADIATION PROFILES IN 105-A LATERAL DRY WELLS SINCE NOVEMBER 1977, AND LETTER TO E.H. CARBOUGH ON RAW WATER LEAK IN 241-A TANK FARM ON FEBRUARY 23-24, 1978"; 12 April 1978; Rockwell International Letter \# 60110-78-003.

Schmidt, W.C., et al., 1978, "HAZARD REVIEW - TANK 105-A OPERATIONS"; RHO-CD-552.

Schmidt, W.C., et al., 1975 "HAZARDS REVIEW - CHEMICAL MLLING AND FLAME CUTTING OF TANK 105-A LINER; ARH-CD-441.

Schulz, W.W. and C.W. Hobbick; "COMPOSITION AND DENSITY OF THE 105-A SOLIDS"; To C.J. Francis and C.H. W. lker; January 12, 1972; DOC 00198; T00218.

Schumacher, E., GIANT LEAK DISCLOSED AT HANFORD (MORE THAN A MILLION GALLONS OF COOLING WATER)

*Shaw, C.B. to Hatch, P., TEST FOR CRACKING CONCRETE - A TANK FARM, 105A, Battelle Pacific Northwest Laboratory 1/9/68, Richland, Washington

*Shaw, H.P., FINDINGS OF A. L. PARME CONCERNING CRACKS IN WASTE TANK DOMES CONTRACT, AT(45-1)-2130, Atlantic Richfield Company, 7/16/69, Richland, Washington

Shefcik, J.J., RL-SEP-269, SPECIFICATIONS AND STANDARDS FOR OPERATIONAL CONTROL OF PUREX SELF-BOILING TANK FARMS, Fission Products Process Engineering, 3/1/65. 
*Shefcik, J.J. WATER SLUICING, 9/24/65.

*Shippell, R.J. to P.F. Mercier/C. Defigh-Price, LINE PRINTER MESH PLOTTER DEVELOPMENT, Richland, Washington Atlantic Richfield Company, 7/29/80

Richland, Washington

Smith, M.J.; "STABLIZATION OF TANK 105-A"; To J.D. Kaser; November 10, 1977; Rockwell International Letter.

Stalos, Stephen; "WATER ADDITIONS TO TANK 105-A"; To J.H. Garbrick; June 2, 1978; Rockwell International Letter.

Stanley, Roger, DOE; "NO SUBJECT"; To Gary Bracken, U.S. Department of Energy; 28 September 1990; WDOE LETTER.

Stivers, H.W., 1959, "PORTLAND CEMENT GROUT VAPOR PRESSURETEMPERATURE TEST"; HW-60556.

Stivers, H.W., 1961, "PROPOSED LEAK DETECTION SYSTEM FOR EXISTING TANKS CONTAINING SELF-BOLING RADIOACTIVE WASTES, SCOPE AND DESIGN CRITERIA)"; HW-68661.

Stivers, H.W. , HW-57289, LEAK DETECTION SYSTEM FOR SELF-BOILING, HIGH LEVEL, RADIOACTIVE WASTES STORAGE TANKS (SCOPE AND DESIGN CRITERIA), 10/7/58.

Stivers, H.W., HW-60749, LEAK DETECTION SYSTEMS FOR ACTIVE TANKS INTERIM REPORT, 6/16/59.

*Stocking, G.T., President; "PUMPOUT PLANS FOR REMAINING LIQUIDS IN CONFIRMED OR SUSPECTED LEAKING TANKS \{Contract AT(45-1)-2130\}"; To O.J. Elgert; 22 March 1977.

Stong, F.S., 1962, "INTERIM REPORT, WASTE TANK LIQUID LEVEL MEASUREMENT SYSTEMS, 200-E AND 200-W AREAS"; HW-72858.

Swanson, J., 1978, "RELEASE OF RAW WATER IN 241-A-TANK FARM"; Occurrence Report \#78-24 (FINAL).

Tyler, W.T. and Winters, H.L., 1984, "LOSS OF CONTROL INSIDE A RADIATION AREA"; Radiation Occurrence Report \#12-84-64. 
Veneziano, T.B.; "SUMMARY OF MEETING WITH DR. CHESTER GRELECKI ON JUNE 23, 1978"; To J.A. Wendland; June 26, 1978; Rockwell Internetional Letter 60412-78-161.

Veneziano, T.B.; "INVESTIGATION OF ASPHALTIC MEMBRANE/NITRIC ACID INTFRACTION FOR TANK A-105"; To F.M. Jungfleisch; May 3, 1978; Rockwell Internationl letter.

Veneziano, T.B.; "FURTHER HEAT-UP STUDIES OF TANK 241-A-105"; To S.S. Bath; October 11, 1978; Rockwell International Letter 60411-78-0454; 000792.

Veneziano, T.B.; To O.R. Rasmussen; October 4, 1977; WHC DSI.

Veneziano, T.B.; To F.E. Boyd; October 27, 1977; WHC DSI.

*Veneziano, T.B., OPENINGS AT TANK 105-A FOR OLYMPIC ENGINEERING SAMPLER/PURGER, 12/6/77.

WASTE STATUS SUMMARY OF 105-A TANK - CAPACITY 1,000,000 GALLONS

*Walker, L.M., TEMPERATURE MONITORING IN TANK 105-A, 1/2/91.

Walker, C.M.; "SUMMARY OF LEAKER OR QUESTIONABLE INTEGRITY

TANKS"; 17 August 1988; WHC Internal Letter \# 13331-88-460 (DRAFT), 2 attachments.

*Walker, C.M., and G.C. Oberg, PROCESS LIMITS AND WASTE DISPOSAL IN A. AX, AND AY FARM TANKS, 4/26/71.

Watkins, J.L., DE-ENTRAINER DESIGN FOR 241-A-105 PORTABLE EXHAUSTER, RI, 11/8/82, Richland, Washington

Weems, M.E.; "TK-105-A, SANDIA LAB SUPPORT"; To J.C. Womack; April 28, 1977; Atlantic Richfield Handford Co.

Wegele, A.E.; "RADIOLOGICAL CONSEQUENCES OF POSTULATED TANK 105-A EXPLOSION"; To T.B. Veneziano; September 13, 1978; Rockwell International Letter \# 72320-78-294; 000783.

Welty, R.K., SD-WM-TI-356, WASTE STORAGE TANK STATUS AND LEAK DETECTION CRITERIA, 9/30/88.

Wodrich, D.D., TANK 105-A "BUMP" PHOTO ON AUGUST 20, 1986, Westinghouse Hanford Company, Richland, Washington 
Wodrich, D.D.; "CLAIM BY OTHERS THAT WASTE TANK EXPLOSION OCCURRED IN 1973"; To Marilyn C. Druby; October 19, 1989; WHC œ Mail.

Wodrich, D.D.; "REQUESTED INFORMATION - CORRECTION"; To Marilyn C. Druby; October 20, 1989; WHC œ Mail.

Wodrich, D.D., 1965, "105-A WASTE STORAGE TANK MODEL TEST"; RL-SEP630.

Wojtasek, R.D.; "CANCELLATION OF THE REQUIREMENT FOR A 105-A EXHAUSTER DE-ENTRAINER"; To R.A. Zinsli; January 21, 1983; Rockwell International Letter \# 65950-83-744.

Womack, J.C.; "PROGRAM FOR STABILIZATION OF TANK 105-A"; To P.M. Nugent; September 16, 1977; Rockwell International Letter.

Womack, J.C.; "PROGRAM FOR STABILIZATION OF TANK 241-A-105"; 4 January 1977; Atlantic Richfield Hanford Co. Letter.

Woodward-Clyde Consultants, 1978, "AN ESTIMATE OF BOTTOM TOPOGRAPHY, VOLUME AND OTHER CONDITIONS IN TANK 105A, HANFORD, WASHINGTON. (WCC PROJECT 13974A - 0300)".

ERDA-1538, FINAL ENVIRONMENT STATEMENT - WASTE MANAGEMENT OPERATIONS - HANFORD RESERVATION, U.S. Energy Research and Development Administration, Washington, D.C., dated December 1975.

Occurrence Report \#75-85 (Final), EXCESSIVE LIOUID LEVEL IN 105-A TANK, 8/5/75.

Occurrence Report \#76-124 (Final), MAXIMUM LIQUID LEVEL LIMIT EXCEEDED, 9/14/76.

Occurrence Report \#78-24 (PRELIMINARY),"RELEASE OF RAW WATER IN 241-A TANK FARM".

Occurrence Report \# 78-49 (FINAL) "RADIATION PEAK INCREASE I 105-A LATERAL 14-05-03 EXCEEDING INCREASE CRITERIA". .

Occurrence Report WHC-90-0186-TFARM, (false alarm), 11/12/90.

SD-WM-TJ-356, WASTE STORAGE TANK STATUS AND LEAK DETECTION CRITERIA, date unknown. 
SOP-TO-080-240 rev A-4 "H $\mathrm{H}_{2}$ ANALYSIS USING VACUUM PUMP AND

REDUNDANT SYSTEMS"; \{Replaces SOP 200.1.25.2\}.

SOP-TO-200-170 \{Replaces SOP 200.2.33.1\}."PROCEDURE FOR WATER FLUSHING THE BULGED BOTTOM LINER IN TK-105-A".

SOP-TO-200-190, ELIMINATION OF WATER ADDITION TO TANK 105-A, 11/28/78.

SOP-TO-200-210; \{Replaces SOP\# 200.2.33\}.1978, "CHEMICAL MILLING OF THE BULGED BOTTOM LINER IN TANK 105-A";

**SOP-TO-040-260, COLLECTION, DELIVERING, AND EVALUATING TANK FARM LIQUID LEVEL DATA, LEAK DETECTION DATA, AND TRANSFER RECORDS, 11/2/76.

SOP-TO-020-320, 1978, "IN TANK SPRINKLING"; \{Replaces SOP 200.2.28\}.

**SOP-TO-200-410, A/AX FARM SLUICING TO AR VAULT, 5/23/78.

**SOP-TO-200-420, IN-FARM SLUICING - 103-A, 11/15/76.

**SOP-TO-200-430, REMOVAL OF THE A TANK FARM FROM THE PRIMARY VESSEL VENTILATION SYSTEM, 7/23/81.

**SOP 200.1.3, TANK FARM PUMPING, GENERAL, 3/6/72.

**SOP 200.1.3, TANK FARM PUMPING - GENERAL, 7/24/72.

**SOP 200.1.3, TANK FARM PUMPING - GENERAL, 8/14/73.

**SOP 200.2.1.1, 241-A.-AX,-AY VESSEL VENTILATION SYSTYM, 1/27/72.

**SOP 200.2.28, IN-TANK SPRINKLING, supersedes issue of 5/25/77, no date.

WHC-EP-0182, TANK FARM SURVEILLANCE AND WASTE STATUS SUMMARY REPORT.

WHC-EP-0182, TANK FARM SURVEILLANCE AND WASTE STATUS SUMMARY REPORT.

WHC Internal letter, "TRANSIENT HEAT TRANSFER STUDY ON TANK 105-A", November 21, 1978, 60413-78-0132. 
A, AX \& AY CONDENSATE \& RAW WATER ADDTN'S TO WASTE STORAGE TANKS, 12/28/77, Richland, Washington

ASPHALT FOR DAMPPROOFING AND WATERPROOFING, 1/18/73, Richland, Washington

BUMPING OF TK 241-A-105, Atlantic Richfield Company, 5/16/66, Richland, Washinton

CHEMICAL MILLING PLAN AND SCHEDULE FOR TANK 105-A, RI, 8/9/78, Richland, Washington

**CONTRACT NO. SA-108, CONSTRUCT, TEST AND EVALUATE MODELS OF A WASTE STORAGE TANK DESIGNATED AS 241-A-105 TANK, SA-108, Atlantic Richfield Company, 9/11/68, Richland, Washington

DRILLING OPTIONS; October 20, 1977; MRN.

ELIMINATE WATER ADDITION TO TK-105-A, Atlantic Richfield Company, Richland, Washington

EXAMPLE OF HYDROGRAPH - DATA WHICH CAN BE INTERPOLATED DURING TANK FILLING, RI, 10/27/77, Richland, Washington

FABRICATION/INSTALLATION INSPECTION PLAN, 18996, Rockwell Hanford Operations 1/6/82, Richland, Washington

Farm Daily Status Report for the period February 1971 through December 1978.

4" TV VIEWING SYSTEM TO EXAMINE A105 BULGE, General Electric, Atlantic Richfield Company, 2/22/78, Richland, Washington

INSPECTION OF CONCRETE CORE SAMPLES TAKEN FROM DOME OF 105-A TANK, General Electric, 3/8/66, Richland, Washington

INSTALL EXHAUSTER ON TANK 105A, 27260, Rockwell Hanford Operations, 1/2/85, Richland, Washington

INTERIM STABLIZATION EVALUATION TANK 241-A-105, RI, 7/31/79 Richland, Washington

LATERAL 1 THROUGH 4 TEMPERATURE PLOT 8/03/81 THROUGH 4/18/83, RI, 4/18/83, Richland, Washington 
LEAK RATES FROM TANKS CONTAINING NO SOLIDS, RI, 10/10/79, Richland, Washington

LETTER ENCOURAGING EMERGENCY PROCUREMENT ACTIONS TO STABILIZE A105, DOE-RL LETTER, RI, Richland, Washington

LIQUID LEVEL TAPE REPLACEMENT OR REPAIR FOR TANK 105A R5, 24748, Rockwell Hanford Operations, 2/7/84, Richland, Washington

105-A, 104-A AND 101-A EXPERIMENTAL RESULTS (SLUDGE AND LATERAL TEMPERATURES), General Electric, RI, 5/30/84, Richland, Washington

105-A WASTE TANK STORAGE, MODEL TEST, RL-SEP-630 General Electric, Richland, Washington

105-A INCDENT FACT SHEET, TANK 241-A-105.

PORTABLE EXHAUSTER OPERATION DATA SHEET 1, TO-060-030, 12/31/82, Richland, Washington

PRE-JOB SAFETY PLAN FOR WORST CASE SIMULATION OF TANK 105-A CHEMICAL MILLING, RI, 4/21/78, Richland, Washington

PROPOSAL FOR WATER ADDITION TO TANK 105-A".

PUMPOUT PLANS FOR REMAINING LIQUIDS IN CONFIRMED OR SUSPECTED LEAKING TANKS,Atlantic Richfield Company, 3/24/74, Richland, Washington

RADIOLOGICAL CONSEQUENCES OF POSTULATED TANK 105-A EXPLOSION, 72320-78-294 RI, 9/13/78, Richland, Washington

SPECIFICATION FOR CONSTRUCTION OF COMPOSITE STORAGE TANKS BLDG. NO. 241, PROJECT 9536, General Electric, 10/15/53, Richland, Washington

STATUS 105-A"; November 8, 1977.

TANK 105-A RISER LOCATION DIAGRAM"

TANK 105-A ORDER TO PULL EQUIPMIENT"

TANK 105-A ELEVATION DATA"

TANK 105-A LIQUID LEVEL READINGS"; 1977 
TANK 105-A DESCRIPTION, STATUS AND SIGNIFICANT HISTORY EVENT SHEET, RI, Richland, Washington

TANK 105-A STABILIZATION_PROGRESS REPORT", January 23, 1978.

TANK 241-A-105 TEMPERATURE FACT SHEET".

TECFINIQUES FOR CALCULATING TANK TEMPERATURES AND SOIL TEMPERATURES NEAR LEAKS - APPLICATION TO PUREX WASTE TANK 105A, BNWL-CC-376 Battelle Northwest, Richland, Washington

THERMAL PROBE ASSEMBLY AND DETAIL TK 105-A"; H-2-34043.

THERMO PROBES UNDER TK 105-A"; sheet 1 of 2; "THERMO PROBES UNDER 105-A TANK"; sheet 2 of 2; H-2-33973.

THERMOCOUPLE AND EXHAUSTER DESIGN INFORMATION, MISCELLANEOUS, RI, Richland, Washington

TOPOGRAPHY AND STEEL RAW DATA FOR BULGE IN A105, RI, 1/1/78, Richland, Washington

1975, 241A TANK FARM STATUS REPORT, Richland, Washington

1975, A TANK FARM LIQUID LEVEL READINGS, Richland, Washington

1976, A TANK FARM LIQUID LEVEL READINGS, Richland, Washington

1977, A TANK FARM LIQUID LEVEL READINGS, Richland, Washington

1977, 241A TANK FARM STATUS REPORT, Richland, Washington

1979, A TANK FARM LIQUID LEVEL READINGS, Richland, Washington

1979, 241A TANK FARM STATUS REPORT, Richland, Washington

1989, NUCLEAR WASTE - DOE'S MANAGEMENT OF SINGLE-SHELL TANKS AT HANFORD, WASHINGTON"; Report to Congressional Requesters; GAO, United States General Accounting Office; GAO/RCED-89-157,.

1990, "ADDITIONAL DOWNTIME, EXHAUSTER P-17 AT TANK A-105"; Process Memo \# 90-101. 
1990, "ADDITIONAL DOWNTIME, EXHAUSTER P-17 AT TANK A-105"; Process Memo \# 90-105.

1990, "ADDITIONAL DOWNTIME, EXHAUSTER P-17 AT TANK A-105"; Process Memo \# 90-117.

1990, "MEETING MINUTES, TANK 241-A-105; 3 FEBRUARY 1965 TO 16 MAY 1966"; TRAC 0053; SST History File \#785. 


\subsection{Sludge and Supernate Analyses}

\section{TK-105-A SLURRY COMPOSITION ${ }^{(1)}$ CURIES/LITER}

\section{Separated Sludge (2) $\quad$ Supernate}

$\begin{array}{lcl}\text { Sr-90 } & 33 & 0.009 \\ \text { Cs-137 } & 6.5 & 8.1 \\ \text { Ce-144 } & 216 & <0.005 \\ \text { Ru-106 } & 68 & <0.02 \\ \text { ZrNb-95 } & 220 & <0.005\end{array}$

(1) On May 1, 1965, sample taken of slurry above settled sludge.

(2) Centrifuged sample 14 volume percent sludge.

The above data are from Reference 3. 


\section{DISTRIBUTION}

\section{Number of Copies}

\section{ONSITE}

15

U.S. Department of Energy-

Richland Operations office

G. J. Bracken

A4-02

R. F. Christensen

A4-02

J. M. Clark (5)

R. E. Gerton

D. G. Hamrick

J. E. Newson (5)

W. W. Rutherford

A4-02

A4-02

R1 - 51

R4 - 04

R3 - 27

Westinghouse Hanford Company

H. Badad

H4 - 23

M. L. Bell

$\mathrm{H} 4-23$

J. B. Billetdeaux

$\mathrm{H} 4-23$

T. D. Blankenship

R2 -30

D. C. Board

J. A. Caggiano Jr.

$S 1-57$

E. J. Campbell

H5-29

J. I. Dearing

B3-30

C. DeFigh-Price

H5 -58

J. L. Deichman

$\mathrm{H} 4-23$

G. T. Dukelow

$\mathrm{H} 4-23$

K. A. Gasper

R2 -97

D. J. Green

$\mathrm{H} 4-23$

C. S. Haller

H5 -53

H. D. Harmon

L6-29

M. N. Is I am

R2 -52

S. Marchetti

R3 -08

E. H. Neilsen (10)

R2 -50

P. R. Praetorius

L6-29

J. G. Propson

S1 -56

T. E. Rainey

R2 - 18

R. E. Raymond (5)

RI -49

I. E. Reep

R1 - 80

Tank Farm Information Center

H4 -23

J. D. Thomson

R2 -95

R. E. Vandercook

R1 -30

S6-07

R. K. Welty

R1-80

D. D. Wodrich

R2 -23

R. D. Wojtasek

DOE-RL Public Reading Room

Document Processing and

Distribution 
WHC-MR-0264

\section{DISTRIBUTION (cont)}

Number of Copies

ONSITE

Westinghouse Hanford Company (cont)

Information Release

Administration (3) L8-07

Central Files L8-04

6

Pacific Northwest Laboratory

B. M. Johson (5)

KI-51

Technical Files

$\mathrm{K} 1-11$ 

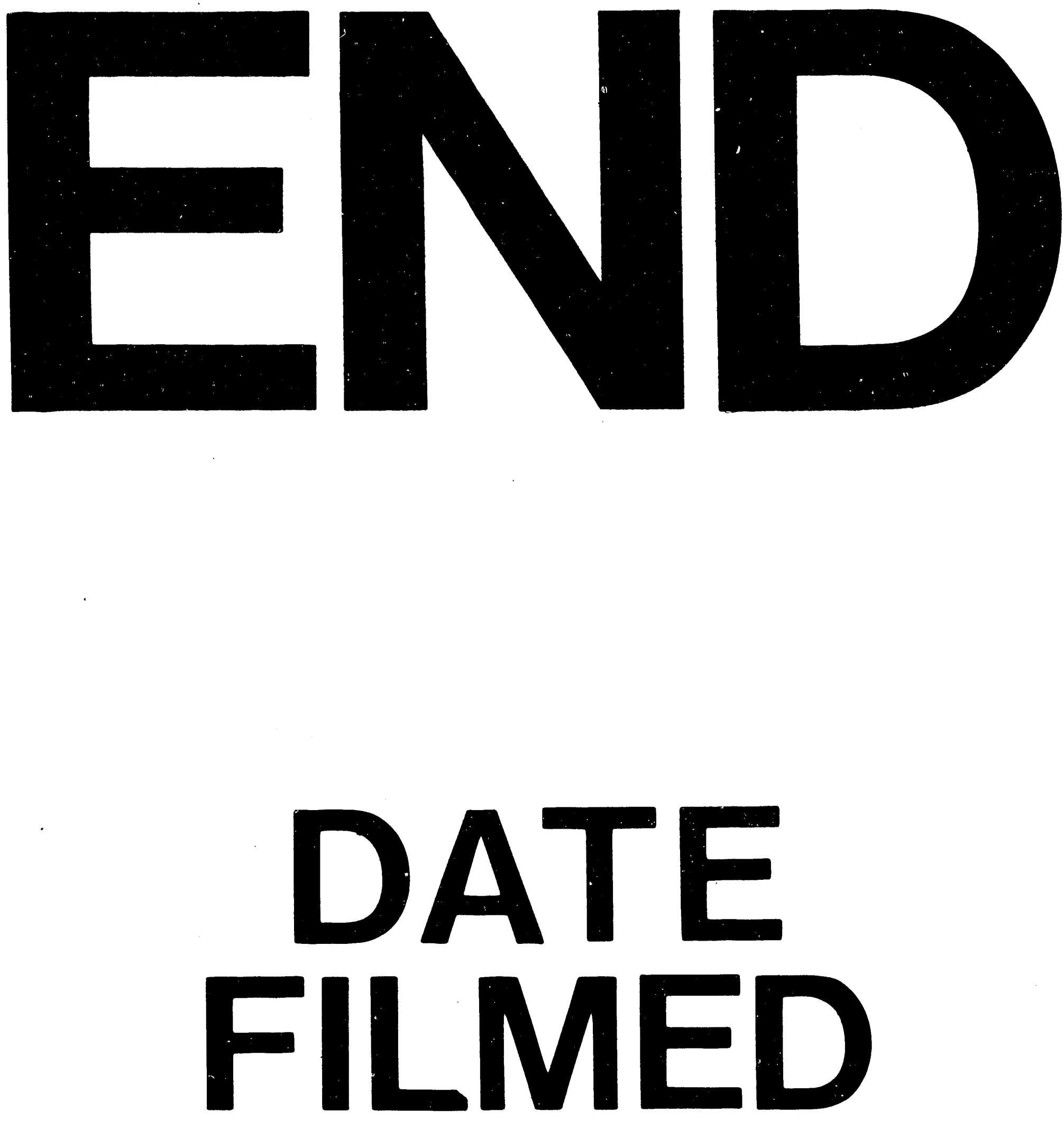

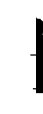

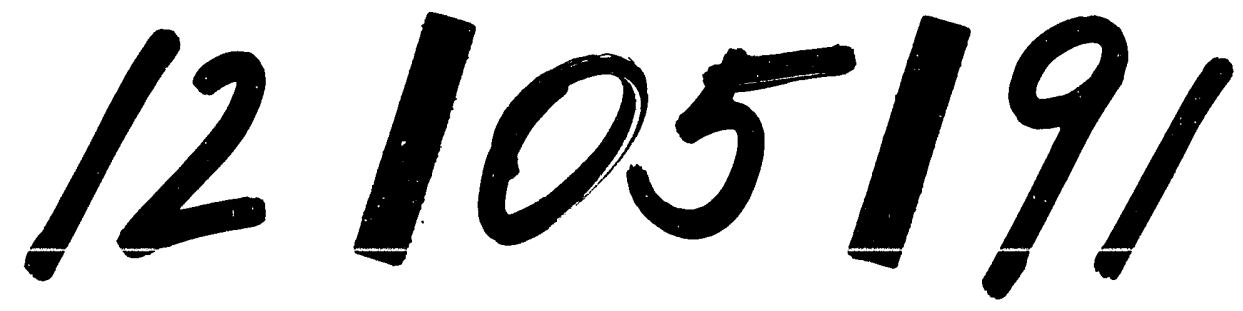


